\title{
Vegetable milks and their fermented derivative products
}

\author{
Neus Bernat ${ }^{a^{*}}$, Maite Cháfer $^{\mathrm{a}}$, Amparo Chiralt ${ }^{\mathrm{a}}$, And Chelo \\ GONZÁlEZ-MARTÍNEZ ${ }^{\mathrm{a}}$ \\ a Instituto de Ingeniería de Alimentos para el Desarrollo. Universitat Politècnica de València, Camino de Vera \\ s/n, 46022 Valencia, Spain \\ ${ }^{*}$ Corresponding author \\ neuberpe@upvnet.upv.es
}

Received: 16 July 2013; Published online: 18 April 2014

\begin{abstract}
The so-called vegetable milks are in the spotlight thanks to their lactose-free, animal protein-free and cholesterol-free features which fit well with the current demand for healthy food products. Nevertheless, and with the exception of soya, little information is available about these types of milks and their derivatives. The aims of this review, therefore, are to: highlight the main nutritional benefits of the nut and cereal vegetable milks available on the market, fermented or not; describe the basic processing steps involved in their manufacturing process; and analyze the major problems affecting their overall quality, together with the current feasible solutions. On the basis of the information gathered, vegetable milks and their derivatives have excellent nutritional properties which provide them a high potential and positive market expectation. Nevertheless, optimal processing conditions for each raw material or the application of new technologies have to be researched in order to improve the quality of the products. Hence, further studies need to be developed to ensure the physical stability of the products throughout their whole shelf-life. These studies would also allow for a reduction in the amount of additives (hydrocolloids and/or emulsifiers) and thus reduce the cost of the products. In the particular case of fermented products, the use of starters which are able to both improve the quality (by synthesizing enhanced flavors and providing optimal textures) and exert health benefits for consumers (i.e. probiotics) is the main challenge to be faced in future studies.
\end{abstract}

Keywords: Nut milk; Cereal milk; Processing; Fermentation 
$94 \mid$ Bernat et al.

\author{
Abbreviations \\ CLSM Confocal laser scanning microscopy \\ CVD Cardiovascular diseases \\ DM-2 Diabetes mellitus type 2; \\ GI Glycemic index \\ MCFA Medium-chain fatty acids \\ MUFA Mono-unsaturated fatty acids \\ PUFA Poly-unsaturated fatty acids \\ SFA Saturated fatty acids \\ UHPH Ultra high pressure homogenization \\ UHT Ultra high temperature
}

\section{Introduction}

Nowadays, there is a global awareness of nutrition-related chronic diseases. In its 2009 annual report on global health risks, the World Health Organization (WHO) determined the distribution of deaths attributable to 19 leading risk factors worldwide. More than half of these factors were nutrition-related: blood pressure due to sodium consumption, cholesterol, obesity, deficiencies of iron and zinc, among others (Stuckler \& Basu, 2011). Increasingly, consumers are more aware of the relationship between nutrition and health. Indeed, newly designed foods are not only intended to satisfy hunger and provide nutrients for humans, but also to prevent nutrition-related chronic diseases and to improve well-being, both physical and mental (Burdock \& Carabin, 2008; Granato, Branco, Nazzaro, Cruz, \& Faria, 2010; S. Kaur \& Das, 2011; Ozen, Pons, $\&$ Tur, 2012). This trend is justified if several factors are considered, such as an increase in public health awareness (a consequence of a more highly educated population), an aging population and their desire for improving the quality of their later years, an increase in healthcare costs, advances in research and technology or changes in government regulations and accountability.

The food market reflects to an ever greater degree the consumer demand for healthy food products. A clear example of this tendency can be seen in the so-called vegetable milks, which are mainly made of nuts and cereals and have a long history in both Eastern and Western cultures. European sales of soya milk and other non-dairy milks are increasing by over $20 \%$ per year; Spain being the EU country in which the non-dairy drinks market grew the most (Organic Monitor, 2006). Similarly, total USA retail sales of soy, almond, rice and other plant milks reached $\$ 1.3$ billion in 2011 (Packaged Facts, 2012).

The best known and most popular vegetable milk derives from soy, although the demand for almond, rice, oat and coconut milks is on the increase. Wide ranges of nut and cereal vegetable milks are currently available on the market in a broad array of formulations: flavored, sweetened/unsweetened, low-fat and/or fortified. Excluding Asia, non-dairy milk alternatives (vegetable milks) still represent a relatively small market overall; nonetheless, the growing awareness of allergy and intolerance issues and the lactose-free, cholesterol-free and low-calorie positioning of these products are bringing about a rise in purchase levels (Stone, 2011). In fact, marketing strategies of those products focus on comparing their health benefits with those of dairy products. Furthermore, experts are starting to consider possible relations between vegetable products and the prevention of cancer, atherosclerosis or inflammatory diseases, since free radicals play a key role in those pathologies and these types of food are an excellent source of antioxidants (Scalbert \& Williamson, 2000). The lactose intolerant and/or those people allergic to cow milk are prime consumers of these types of milks, but they are also in great demand by people without health problems, such as vegans and vegetarians.

The development and further increase in demand of such products would have an extra advantage, which could be of economic interest for many countries: the raw material they de- 
Nut and cereal vegetable milks $\mid 95$

rive from (nuts and cereals) do not generally require specific soil nor climatic conditions, they are able to adapt to different climates although, of course, the productivity might change (Osca, 2007; Coniglio, 2008). For example, almond tree farming is considered to be a dry cultivation with low soil fertility, low rainfall and minimum pruning and plant protection requirements (Navarro-Muñoz, 1996; Saura, Cañellas, \& Soler, 1988). Oat is a temperate crop which grows well in damp, marginal upland areas (Welch \& McConnell, 2001). These facts would benefit the rapid implementation of these raw materials in non-cultivated lands around the world and maybe, this could contribute to the rural development of developing countries and allow these vegetable products to attain highly competitive prices within the world market.

Taking into account the positive trends of these products in the food market and bearing in mind that the literature contains little information about them, the aims of this work are to: highlight the main nutritional benefits of these kinds of milks, fermented or not; describe the basic processing steps involved in their manufacturing process; and analyze the major problems affecting the overall quality, together with the possible solutions currently available. Therefore, this review focuses on the study of nut and cereal vegetable milks available on the market and their fermented derivatives.

\section{Types of nut and cereal vegetable milks and their nutritional benefits}

All the commercial vegetable milks share common features such as being lactose-free, animal protein-free or cholesterol-free. Taking into account the raw materials and their nutritional and health properties, vegetable milks can be broadly classified in two large differentiated groups: nut and cereal milks. Both kinds of products are in the state of the art owing to the new-knowledge impact of their compounds on some current chronic diseases, such as cardiovascular diseases (CVD), type 2 Diabetes mellitus (DM-2), obesity and some cancers. These metabolic diseases are linked with our daily lifestyle, notably an unbal- anced energy-rich diet, lacking in fiber and protective bioactive compounds, such as micronutrients and phytochemicals (Fardet, 2010). All these limited nutrients commented on above are readily available in both cereals and nuts.

Apart from nuts and cereals, other raw materials have been used industrially, such as tubers (e.g. tigernuts) and plants (e.g. hemp, sunflower...). However, these milky based products are only well accepted in specific countries. Despite its local commerce, tigernut milkshas also been explained in detail in this review due to its interesting composition and health properties.

\subsection{Cereal grains and their milks}

Cereals are known as a good source of the necessary daily energy, vitamins, several minerals, dietary fiber and phytochemicals, including phenolic compounds, carotenoides, vitamin E, lignans, inulin, starch, sterols and phytates (Okarter \& Liu, 2010; J. L. Ward et al., 2008). The chemical composition of those cereals whose vegetable milk has been commercialized is summarized in Table 1. With respect to the supply of vitamins, cereals are considered an important source of group B vitamins, especially thiamin, riboflavin, folates and niacin (McKevith, 2004). Dietary fiber is present in large quantities and this is rich in fructo-oligosaccharides, which are reportedly effective at stimulating the growth of Bifidobacteria and Lactobacilli in the human intestine (K. D. Kaur, Jha, Sabikhi, \& Singh, 2011). Besides this prebiotic effect, their phenolic compounds have also been reported to possess gastroprotective properties, in addition to their antioxidant, cholesterol-lowering, anti-atherogenic, anti-carcinogenic and anti-inflammatory effects (C. Chen et al., 2004; Dykes \& Rooney, 2006; Prior \& Gu, 2005). Indeed, epidemiological studies have shown an association between increased wholegrain consumption and reduced risks of various types of chronic diseases, such as CVD, obesity, DM-2 and some cancers (Chan, Wang, \& Holly, 2007; de Munter, Hu, Spiegelman, Franz, \& van Dam, 2007; Esmaillzadeh, Mirmiran, \& Azizi, 2005; Larsson, Giovannucci, Bergkvist, \& Wolk, 2005; Mellen, Walsh, \& Herrington, 2008; Murtaugh, Jacobs, Jacob, Steffen, \& Marquart,

IJFS | April 2014 |Volume 3 |pages 93-124 
2003; Schatzkin, Park, Leitzmann, Hollenbeck, \& Cross, 2008; van de Vijver, van den Bosch, van den Brandt, \& Goldbohm, 2009). More specific properties and health benefits of each cereal grain whose vegetable milk has been commercialized are summarized in Table 4.

In order to gain the greatest benefit from the health properties of cereals, several aspects have to be considered. For instance, it is important to use and consume whole grain and not the refined, since most of the health components are located in the bran and germ. So, the use of the whole grain is highly recommended when producing the cereal milks. Another point to consider is the anti-nutrient content in some cereals, primarily phytic acid (mineral chelator) or saponins (toxic in high amounts and bitter tasting), although their presence can be reduced and/or eliminated by pre-treatment processes such as grinding, soaking, heat treatments, fermentations and germinations (Brady, Ho, Rosen, Sang, \& Karwe, 2007; Sharma \& Kapoor, 1996; Zhu et al., 2002). Despite the antinutritional components, so beneficial are wholegrain cereal's properties that important food authorities, such as the U.S. Department of Agriculture (USDA), have strongly recommended 611 servings of grain products daily (Dewanto, Wu, \& Liu, 2002).

\subsection{Nuts and nut milks}

Due to their composition, nuts and nut-based products have recently attracted a great deal of attention from food, nutrition and health specialists. Table 1 shows the chemical composition of those nuts whose vegetable milks have been commercially produced. Nuts are rich in mono- (MUFA) and polyunsaturated fatty acids (PUFA), vegetable proteins, dietary fiber, phytosterols, polyphenols, vitamins and minerals (Phillips, Ruggio, \& Ashraf-Khorassani, 2005; Segura, Javierre, Lizarraga, \& Ros, 2006). Most of those compounds have antioxidant properties and are proven to provide a beneficial effect on plasma lipid profile, low-density lipoprotein (LDL) oxidation and inflammatory processes, among others (Carlson, Eisenmann, Norman, Ortiz, \& Young, 2011; Egert, Kratz, Kannen- berg, Fobker, \& Wahrburg, 2011; Gillingham, Harris-Janz, \& Jones, 2011; Jones et al., 2011; Liu, 2012; Myers \& Allen, 2012; H. A. Ward et al., 2012; Whent et al., 2012). Additionally, Vinson and Cai (2012) analyzed the antioxidant efficacy in different nuts, obtaining the following order of importance: walnut $>$ cashew $>$ hazelnut $\approx$ almond. Epidemiological studies have linked frequent nut consumption to a reduced risk of CVC, DM-2 or death by all-cause mortality (Kelly \& Sabate, 2006). Moreover, Li et al. (2009) observed that an increase in nut consumption was significantly associated with a more favorable plasma lipid profile, including lower LDL cholesterol, total cholesterol and apolipoprotein B-100 concentrations; but they did not observe significant associations with nonhigh-density lipoprotein (HDL) cholesterol or inflammatory markers. Furthermore, nuts have a high $\mathrm{K} / \mathrm{Na}$ ratio, which contributes to maintain well-balanced electrolytes in the human body, and, in addition to the prebiotic effect of their dietary fiber commented on above, the carbohydrates from nuts are complex (low Glycemic Index (GI)), which help to maintain blood sugar at healthy levels.

In spite of the fact that around $50 \%$ of a nut is made up of lipids, regular nut consumption within a balanced diet has been shown to improve humans' lipid profile, increase endothelial function and reduce inflammation, without causing weight gain (C.-Y. Chen, Lapsley, \& Blumberg, 2006; R. D. Mattes, Kris-Etherton, \& Foster, 2008; Salas-Salvado, Casas-Agustench, Murphy, Lopez-Uriarte, \& Bullo, 2008; Zambón et al., 2000). Thus, in addition to providing both nutrients and bioactive antioxidants, nut milks may be a useful dietary tool for reducing risk factors that cause diseases with a major mortality rate in developed countries, such as metabolic syndrome, DM-2 or CVD. Indeed, the U.S. Food and Drug Administration approved a health claim between nuts and heart disease, suggesting that $42 \mathrm{~g}$ per day of most nuts as part of a low saturated-fat and cholesterol diet may reduce the risk of heart disease (FDA. U.S. Food and Drug Administration, 2003). The European Food Safety Authority (EFSA) also published a scientific opinion on the substantiation of health claims related to nuts and essential fatty acids (omega- 
Nut and cereal vegetable milks $\mid 97$

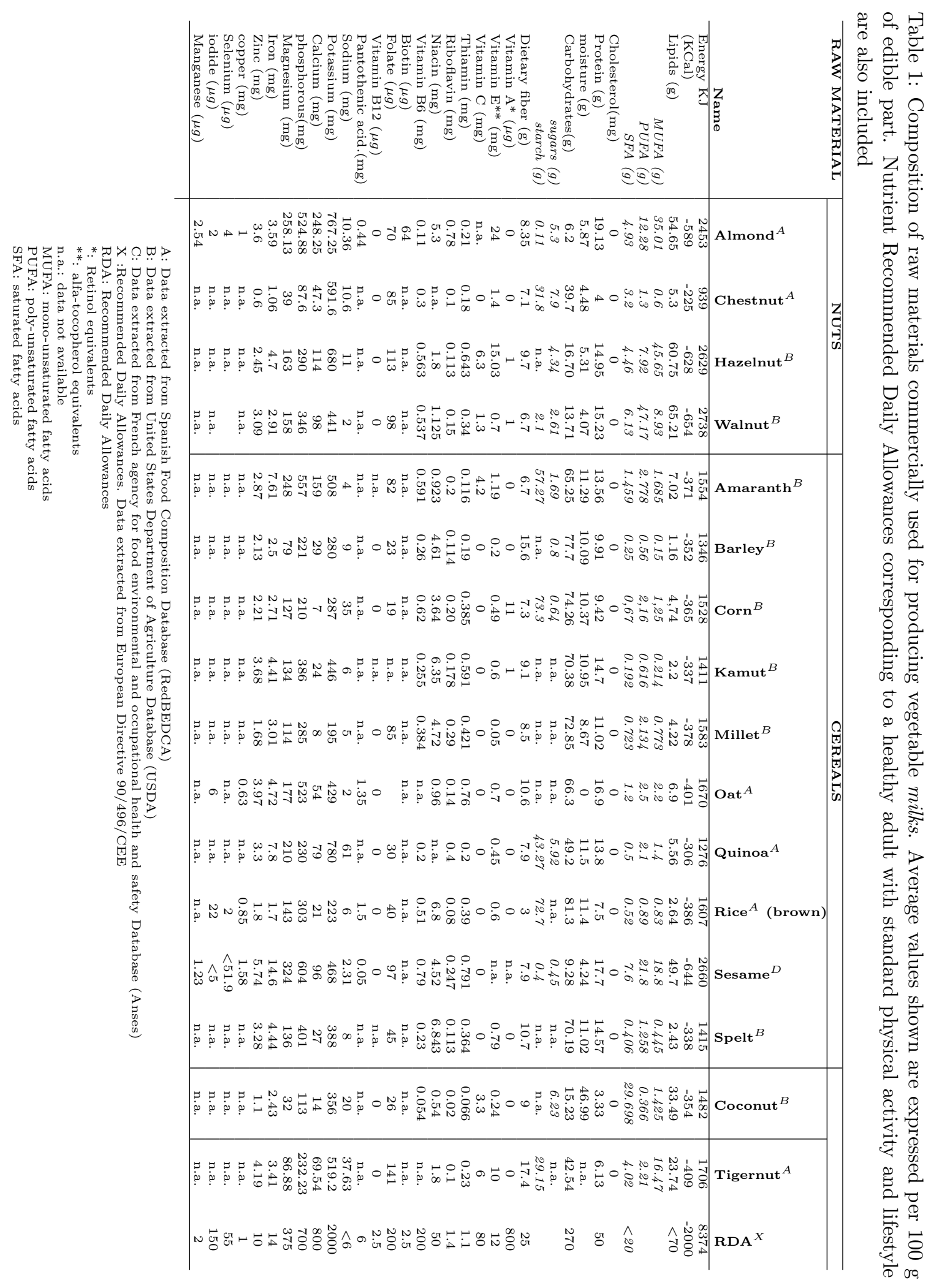

IJFS | April 2014 | Volume 3 | pages 93-124 
$98 \mid$ Bernat et al.

3/omega-6) in nut oil, which is related to antiinflammatory, heart health, weight management and healthy cardiovascular system effects (Agostoni et al., 2011).

Although coconut is commonly classified as a nut, its composition does not follow the trend of this food group (Table 1), which means that not all of the above-mentioned health properties of nuts are associated with it. As can be seen in the chemical composition of coconut (Tables 1 and 4), the particularity of this traditional milk from the Asian, African and Pacific regions is its medium chain fatty acid (MCFA) lipid profile, which is similar to human milk (Chiewchan, Phungamngoen, \& Siriwattanayothin, 2006); the most predominant is lauric acid (45-53\% of total coconut fats) and this MCFA was reported to be antibacterial, antiviral and antifungal (Raghavendra \& Raghavarao, 2010). In spite of the lipid profile being mostly saturated, Enig (2004) reported that MCFA are absorbed directly from the intestine and sent straight to the liver to be rapidly metabolized for energy production and, thus, they do not participate in the biosynthesis and transport of cholesterol. Furthermore, the high amount of antioxidants determines the long shelf-life of this vegetable milk and is good for the health. Other interesting health benefits are summarized in Table 4 .

Tigernuts are another interesting source of raw material to be used for the production of vegetable milks. The major components (Table 1) of this tuber are complex carbohydrates, mainly starch and dietary fiber, which provide vegetable milk with low GI. Furthermore, the protein content is rich in arginine, which liberates hormones that produce insulin; thus being suitable for diabetics (Adejuyitan, 2011). Besides its antioxidant compounds, the lipid profile of tigernuts is similar to that found in olive oil; therefore, the derived milk has a positive effect on the cholesterol level. Other interesting health benefits are detailed in Table 4.

More specific properties and health benefits of each nut whose derived vegetable milk has been commercialized are summarized in Table 4.

\section{$3 \quad$ Vegetable milk processing}

Industrial vegetable milk processing is based on five main steps: grinding, water extraction, filtration, homogenization and pathogen removal treatment. Nevertheless, depending on the raw material and the desired final product characteristics, the process slightly differs. Thus, the processing is subsequently explained separately, taking into account the different groups of these above-mentioned milks commented upon.

\subsection{Cereal milk processing}

A typical flow diagram of cereal milk processing is shown in Figure 1. Before going through the extraction procedure, cereals are conditioned: this mostly refers to husking, washing and grain classification. Pre-conditioning is a requisite for Quinoa grain due to its saponins' content (toxic in high amounts and imparts a bitter taste). Mechanical abrasion and/or washing are sufficient to remove this unwanted compound (Brady et al., 2007).

Once the cereal grain is conditioned, it is submitted to a coarse dry grinding to facilitate the subsequent water extraction. This water extraction process is usually carried out in colloidal mills by adding hot water and the ground cereal at the same time. The colloidal mills are used to reduce the particle size of the solid in aqueous suspension by applying high levels of hydraulic shear to the process liquid. The amount of water added would depend on the final pre-established concentration. This step is carried out in hot conditions, on one hand, to ease the extraction of soluble compounds and, on the other hand, to provoke starch gelatinization and improve the subsequent enzymatic treatment. The main difference observed between these and other types of vegetable milks is this enzymatic treatment which they are submitted to after the extraction procedure. This step is needed to attain the low viscosity which the consumer demands of these products. This viscosity is provided mainly by starch and other polysaccharides after the thermal treatments.

After removing the non-extracted solids, the milky liquid obtained is then temperature ad- 
Nut and cereal vegetable milks $\mid 99$

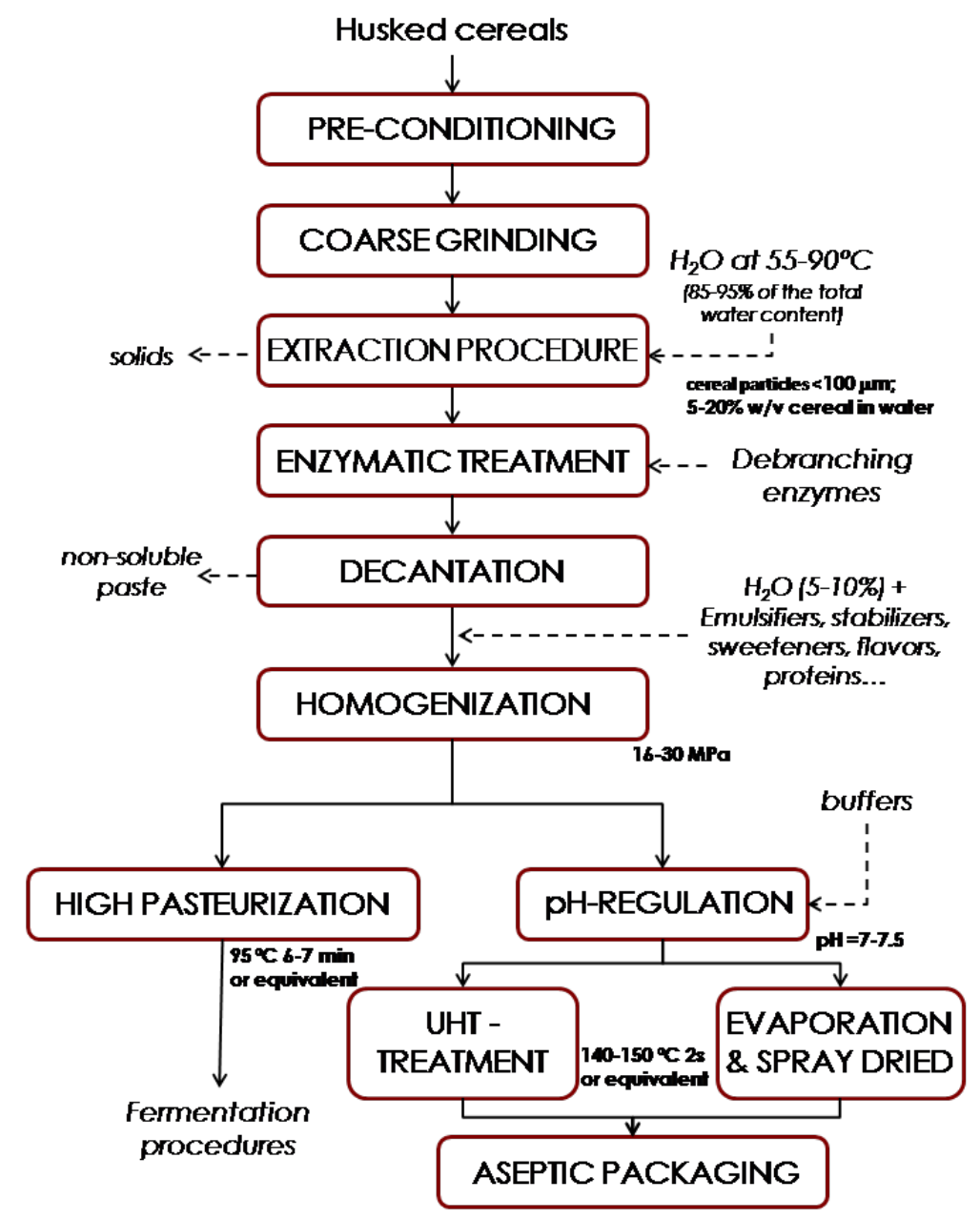

Figure 1: Typical cereal milk processing flow diagram.

justed and $\mathrm{pH}$ adjusted, with appropriate buffers, to the optimum level for the enzymatic treatment. The $\mathrm{pH}$ values, temperature and the time-remaining would depend on the types of enzymes used and those would be chosen taking into account the final product's desired viscosity, sugar content and/or texture parameters. Generally, enzyme composition comprises mainly $\alpha$ amylase and $\beta$-amylase activities and is devoid of $\beta$-glucanase and proteinase activities, since glucans and proteins have interesting nutrient value and their degradation is not desirable (Triantafyllou, 2002). When the desired textural properties are reached, a homogenization process is applied to ensure physical stabilization during the product's shelf life. The usual homogenization pressures range between $16-30 \mathrm{MPa}$, although some researchers are studying the use of ultra-high pressures $(\mathrm{UHPH},>150 \mathrm{MPa})$ in vegetable milk production (Bernat, Chafer, A., \& González-Martínez, 2011; N. Cruz et al., 2007; Valencia-Flores, Hernandez-Herrero, Guamis, \& Ferragut, 2013). Food additives, such as emulsifiers (lecithin), stabilizers (hydrocolloids), sweeteners, either natural (sucrose, fructose or glucose syrups from agave, corn, rice or wheat) or synthetic (acesulfame K, aspartame or sucralose) and, sometimes, flavoring agents (cocoa, soluble 
coffee, vanilla or cinnamon) are often introduced before the homogenization step. The amounts of these additives incorporated ranged from 0.4$2.5 \%(\mathrm{w} / \mathrm{v})$ in emulsifiers, $0.025-0.3 \%(\mathrm{w} / \mathrm{v})$ in stabilizers, $5-8 \%(\mathrm{w} / \mathrm{v})$ in sweeteners and $0.5-3$ $\%(\mathrm{w} / \mathrm{v})$ in flavoring agents (Erra, 2012; Pereyra \& Mutilangi, 2012; Triantafyllou, 2002; Marti, Martinez, Miralles, \& Perez, 2010). Further information on the ingredients used to formulate already commercialized cereal milks is shown in Table 2.

To ensure quality and safety, after having readjusted the $\mathrm{pH}$ to standard values of milks with buffers such as sodium carbonates, potassium carbonates, sodium hydroxides or potassium diphosphates (Erra, 2012), homogenized milks are either heat treated or spray dried and finally aseptically packaged. Heat parameters of temperature, time and pressure would be stipulated taking into account the type of product, the particle size, viscosity, initial microbial load and stability of components under thermal conditions. The inactivation conditions of the enzymes previously used is also a variable when choosing heat parameters, since this step is also used to eradicate the activities of residual enzymes. Ultra High Temperature (UHT) treatment is commonly chosen $\left(140-150^{\circ} \mathrm{C}, 2 \mathrm{sec}\right)$ or high pasteurization $\left(95^{\mathrm{O}} \mathrm{C}>6 \mathrm{~min}\right.$ or equivalent treatment) might also be used when the milks product is to be fermente(Erra, 2012; Pereyra \& Mutilangi, 2012; Marti et al., 2010; Triantafyllou, 2002).

The final milky product chemical composition of major components (protein, lipids and carbohydrates) in different types of cereals is summarized in Table 2. Considering these milks are to be used as substitutes for cow milk, it is remarkable that there is a high fiber content and a low lipid content with a better profile than standard milk.

\subsection{Nut milk processing}

The general industrial flow diagram of nut milk production is presented in Figure 2. The steps shown are mostly the same as in cereal milk processing but the enzymatic treatment is removed, since the low starch content of these nuts do not confer a negative effect on the viscosity of the final product.
Nut conditioning consists of washing and selection, plus a blanching treatment in order to facilitate both the further peeling of nuts and the initial microbial load reduction. In view of the fact that no enzymes are used, possible food additives such as emulsifiers, sweeteners, hydrocolloids and/or flavors can be introduced during the grinding step, and thereby facilitate the optimal dispersion of ingredients. The types of food additives chosen are the same as the ones mentioned in cereal milk processing.

The final milky product chemical composition of major components (proteins, lipids and carbohydrates) in different types of tree nuts is summarized in Table 2. In spite of the fact that the over $50 \%$ of a nut's content is made up of lipids (Table 1), final contents end up with lower values than non-defatted cow milk, which varies from 3 to 5 $\%(\mathrm{w} / \mathrm{v})$. Moreover, considering these vegetable milks are to be used for the same purposes as cow milk, the (MUFA+PUFA)/SFA ratio (SFA, Saturated Fatty Acids) is much higher than other animal milks and, hence, they are healthier. Almond milk stands out among other nut milks as being an appropriate alternative to cow milk, since, besides the lipid profile, it has a low ratio of $\mathrm{Na} / \mathrm{K}$ and a balanced ratio of $\mathrm{Ca} / \mathrm{P}$ (Luengo, 2009).

In the production of tigernut milk, the preconditioning step is more complex: in the extraction procedure, tigernuts need to be softened prior to the milling process (by rehydration with water for around 18 hours) and a preliminary germicidal treatment (active chlorine) is required to decrease the initial microbial load (it is a tuber) (CRDO: Consejo Regulador de la Denominación de Origen Chufa de Valencia, 2012; Sanful et al., 2009). Also, an enzymatic treatment is required due to the high starch content of this nut, as has been commented on above for the cereal milks manufacture.

In industrial coconut milk production, the coconut meal has to be obtained by shelling, paring and washing. After that, coconut meal is submitted to a blanching process reinforced with chemical agents, such as $\mathrm{NaHSO}_{3}$, for different purposes: facilitate the removal of the brown testa, enhance oxidation stability due to inner enzyme denaturation and facilitate further grinding. Once coconut meat is ground and water 
Nut and cereal vegetable milks |101

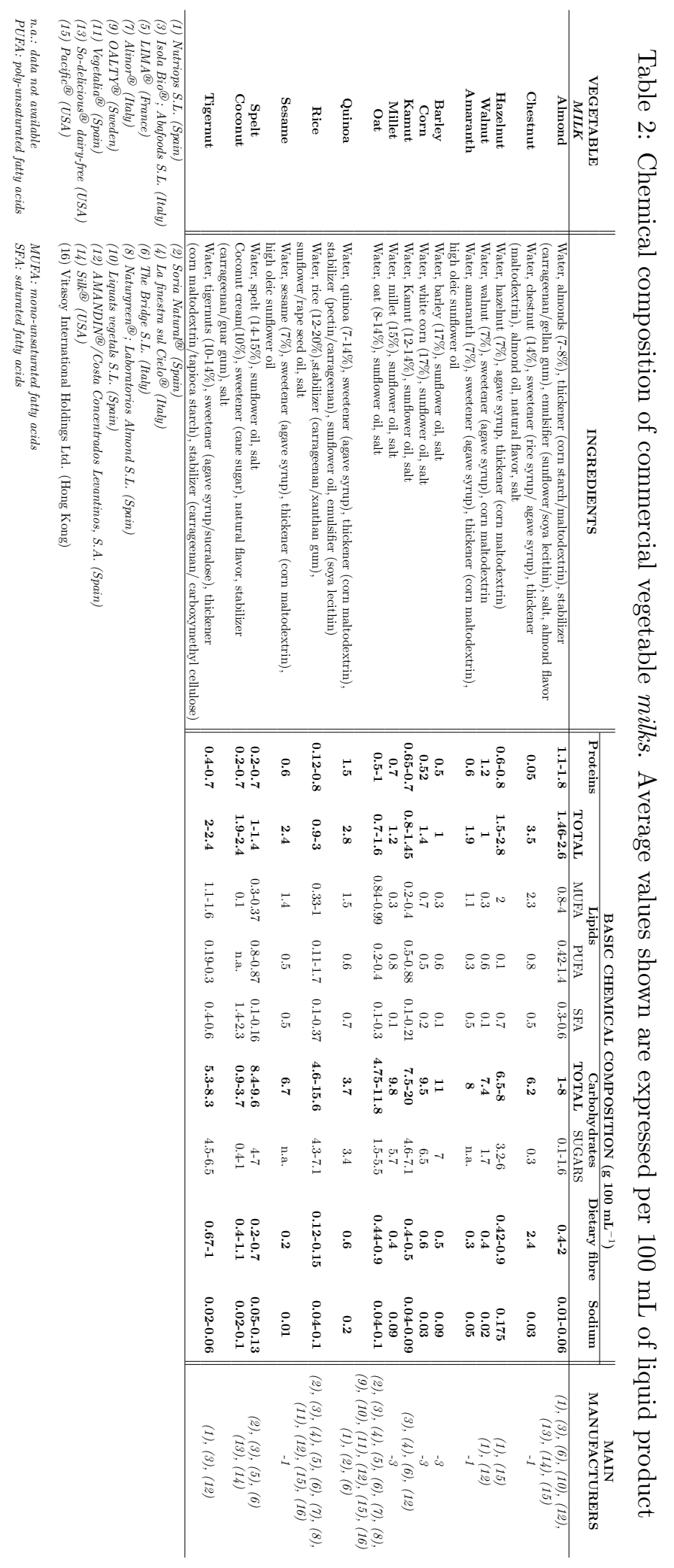

IJFS | April 2014 | Volume 3 | pages 93-124 
$102 \mid$ Bernat et al.

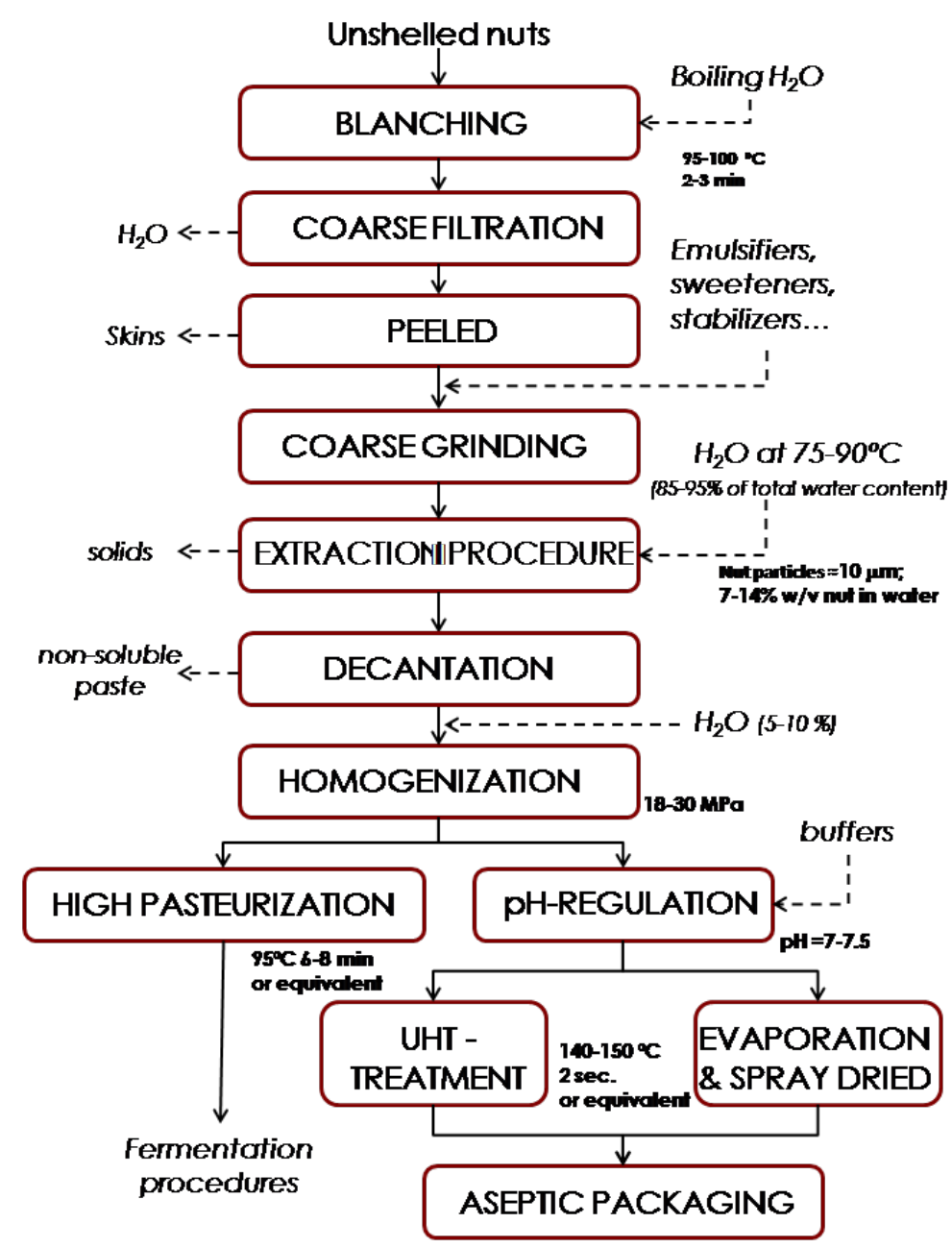

Figure 2: Typical nut milk processing flow diagram.

extraction is developed, the milky liquid is finally filtrated using double layers of cheese cloth (Mepba, Achinewhul, \& Pillay, 2009).

The major technological problem found during the processing or shelf life of these cereals and nut derived milks is related with the low physical stability of the liquid dispersion, usually with low viscosity, which promotes the phase separation of the unstable fat globules caused by flocculation and coagulation phenomena in a short period of time. Moreover, fibers and non-soluble material will also separate, either by sedimentation or floatation, thus contributing to the watery effect of the product. The employment of an optimal thermal treatment and homogenization pressures during the milk processing, the addition of both amphiphilic compounds and hydrocolloids or the use of UHPH could contribute to the development of an excellent product with desirable sensory attributes. Using UHPH allows for a longer shelf life of the product, since greater physical stability is achieved mainly due to a reduction in the size of the fat globule that prevents coalescence. Figure 3 shows pictures of hazelnut milk obtained by means of the Confocal laser scanning microscopy (CLSM) technique in which the effect of UHPH is proved; as can be seen, almost all the fat globules in untreated 

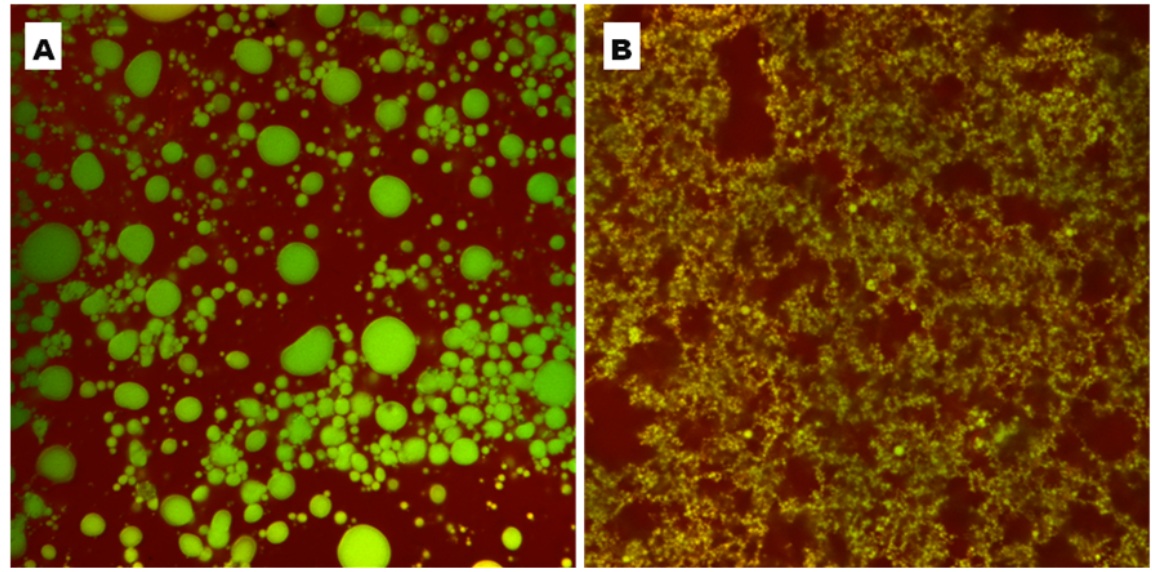

Figure 3: Confocal pictures of hazelnut milk non-treated (A) and homogenized at $172 \mathrm{MPa}(\mathrm{B})$, where fat globules appeared green-yellow colored. Source: personal compilation, University of Valencia

milk (Fig. 3A) are aggregated, while in that which has been UHPH-treated (Fig 3A), not only are the fat globules non-aggregated but they are also distributed, forming a kind of network that enhances physical stability. Sometimes homogenization pressures are also capable of reducing the microbial load of the product prior to the thermal treatment, if they are greater than 200 MPa (N. Cruz et al., 2007; Pereda, Ferragut, Quevedo, Guamis, \& Trujillo, 2007; ValenciaFlores et al., 2013). Despite the advantages, this emergent technology is being only used in a laboratory and pilot-scale due to the high investment costs. Hence, as can be seen in Table 2, the vegetable milks processing industry normally use hydrocolloids and emulsifiers to prevent phaseseparation in developed products.

\section{Fermentation of vegetable milks}

Besides the direct consumption of vegetable milks, they might be also used as raw materials to develop yogurt-type products, as has been done with soy milk. Hence, these newly fermented products would satisfy a market sector focused on the current consumers' demand of non-dairy products.

In this regards, nut and cereal milks are considered as good substrates for the growth of different strains, owing to the presence of non-digestible components with prebiotic properties in both vegetable matrices. Thus, starch and fiber materials are reported to enhance the physical stability of the fermented vegetable milk and to promote the survival of the starters used, not only due to their nutritional contribution but also, since fibers are resistant to gastric juices, they act as protective barriers within the human gastrointestinal tract, (Bosnea et al., 2009; Patel, Pandiella, Wang, \& Webb, 2004; Perrin, Grill, \& Schneider, 2000; Wang, Conway, Brown, \& Evans, 1999). Nevertheless, the ability of the starter microorganism to grow in these vegetable raw materials varies largely with the strain. Therefore, studies into bacterial survival are required prior to processing the fermented product.

Most of these innovative fermented products found in the literature have been developed by using probiotic bacteria from Bifidobacteria, Lactobacillus and Streptococcus genera. If probiotic bacteria are used as starter microorganisms, the newly designed product would have an added value, owing to the health benefits that these type of bacteria can exert. Although oat is often used as a raw material, other matrices have also been studied, such as almond, hazelnut or rice. A list of these has been summarized in Table 3. 
104 Bernat et al.

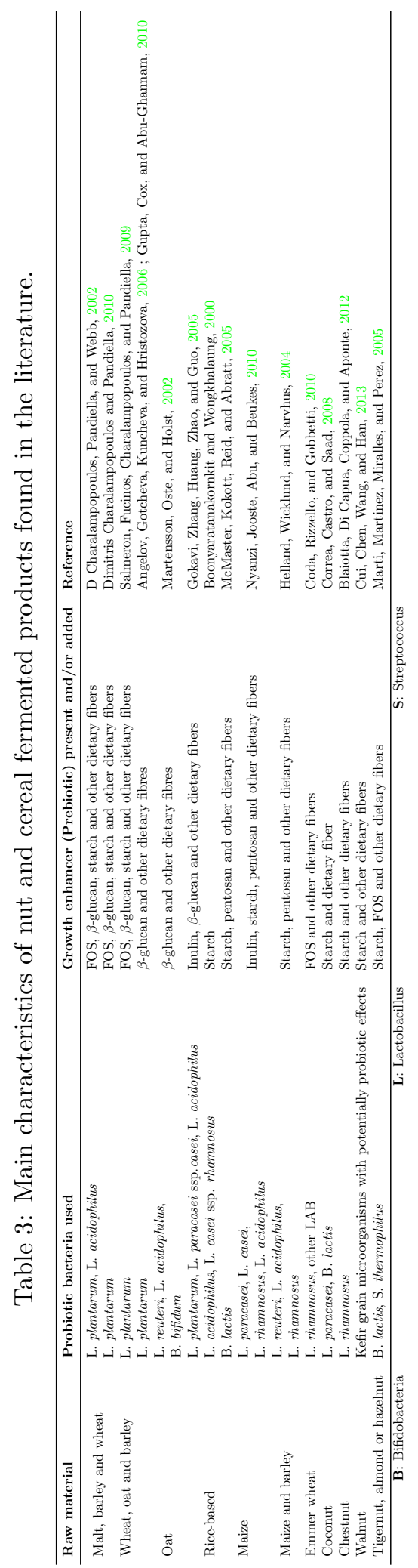

IJFS | April 2014 | Volume 3 | pages 93-124 
Nut and cereal vegetable milks $\mid 105$

\subsection{Processing of fermented vegetable milk}

General industrial processing used to develop nut and cereal fermented vegetable products is based on four main steps: the procedure to obtain vegetable milk previously commented on above (Figures 1 and 2), conditioning the milk until the optimal starters' growing temperature is reached, the inoculation and incubation procedures (fermentation) and cooling to $4{ }^{\circ} \mathrm{C}$. Nevertheless, depending on the raw material, the type of starters used and the final product features, the whole process may differ.

Some additives are frequently introduced into the vegetable matrix, mainly sugars and prebiotics (as growth enhancers), to promote the viability of bacteria and to reduce the length of the fermentation process (in order to avoid crosscontamination problems). Mono and oligosaccharides, some prebiotics such as inulin, $\beta$ glucans and dietary fibers have been the growth enhancers most commonly used by different authors (Akalin, Tokusoglu, Gonc, \& Aycan, 2007; Gokavi, Zhang, Huang, Zhao, \& Guo, 2005; Ozer, Akin, \& Ozer, 2005; Rosburg, Boylston, \& White, 2010; Sendra et al., 2008). Potentially, prebiotics are naturally present in both cereals and nuts (i.e. dietary fiber); nevertheless, prebiotic compounds are sometimes added in order to increase the product's health benefits or its technological properties, since the majority are able to increase the viscosity of the milk.On the other hand, hydrocolloids, such as carrageenan and xanthan gum, are often added to prevent syneresis and, thus, ensure the physical stability of the product during the stated shelf life. Nonetheless, if the raw material used naturally contains these types of compounds, it might not be necessary to add them during the industrial processing (i.e. $\beta$-glucans present in oat milkz). Prior to the addition of the starter inoculum, pathogen-free milks must be conditioned to reach the fermentation temperature. This is usually around $37{ }^{\mathrm{O}} \mathrm{C}$, but it depends on the optimal growth temperature of the starter bacteria used. With regards to the fermentation time, much longer is usually needed than during standard cow milk yogurt production, since potential pro- biotic bacteria (type of bacteria currently chosen to develop these foodstuffs due to the added value on the final product) have more complex nutritional requirements (Severson, 1998), especially when growing in vegetable matrices. The reported fermentation times have been found to be around 16-24 h if no growth enhancers are used in the formulation (Dimitris Charalampopoulos \& Pandiella, 2010; D Charalampopoulos, Pandiella, \& Webb, 2002; Coda, Rizzello, \& Gobbetti, 2010; Correa, Castro, \& Saad, 2008; Blaiotta, Di Capua, Coppola, \& Aponte, 2012; Cui, Chen, Wang, \& Han, 2013; Gokavi et al., 2005; Gupta, Cox, \& Abu-Ghannam, 2010; Martensson, Oste, \& Holst, 2002). The fermentation procedure finishes when the $\mathrm{pH}$ value of milks reaches 4.2-4.5. Immediately afterwards, the fermented products are sealed, cooled to 4 ${ }^{\mathrm{o}} \mathrm{C}$ and stored at refrigeration temperatures.

The major challenges affecting these fermented products are related to the sensory quality (appearance and texture) and the resistance of the probiotic microorganisms. Most of these fermented products might have physical stability problems caused by phase separation between components (usually proteins coagulate, forming a non-continuous weak gel, and serum separation occurs at the very beginning of storage time or during storage period). This structure can be observed in Figure 4, where the microstructure is shown of an oat fermented milk with probiotic L. reuteri and S. thermophiles obtained by using CLSM. As can be observed, the aqueous continuous phase is not completely entrapped in the non-continuous protein-fiber network.

The appearance of these products is often very similar to that observed in a low-fat stirred yogurt. To promote physical stability during the acidification process, hydrocolloids are generally used, as has been commented on above. The most common hydrocolloids used as thickening agents are xanthan gum, modified starches, pectin and cellulose derivatives, among others. Nevertheless, other tools have been used to promote better textural properties. For instance, Martensson, Oste, and Holst (2000) selected strains able to produce exopolysaccharides (EPS) in order to obtain oat-based fermented products. Yoghurts with EPS-producing bacterial strains showed higher viscosity and less phase separa-

\begin{tabular}{l|l|l|l} 
IJFS & April 2014 & Volume 3 & pages 93-124
\end{tabular} 


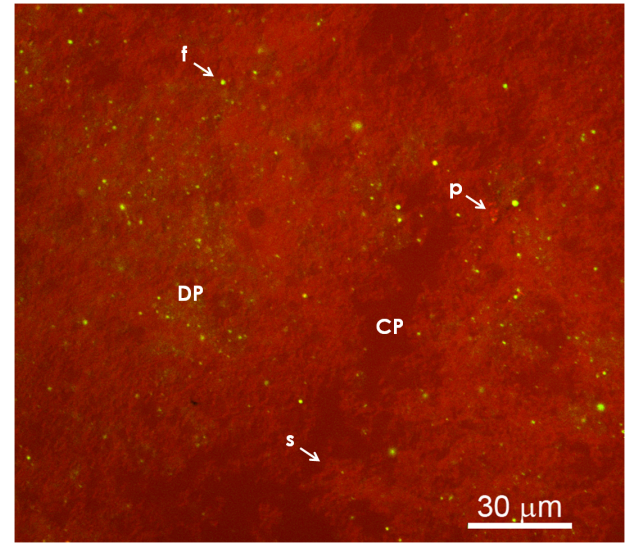

Figure 4: Microstructure obtained by CLSM of fermented oat milk with a mixed culture of $\mathrm{L}$. reuteri and S. thermophilus. (CP: Continue phase; DP: Dispersed phase; f: fat globule; s: starters + other fibers). Source: personal compilation, University of Valencia

tion in comparison with yoghurts made with strains not producing EPS. This structural property would give rise to a new generation of in situ produced thickeners. This is of general interest, as there is an increasing demand from manufacturers to decrease the addition of stabilizers in yoghurt products.

N. S. Cruz et al. (2009) instead, studied the effect of UHPH treatments (around 250-300 MPa) in soy milk on the fermentation processing. This technology is quite similar to the conventional high-pressure homogenization used in the food industry but considerably higher pressures are applied. Some benefits have been reported for its application in the food industry as it causes interesting changes in structural components and increases the shelf-life of liquid products. The results showed that UHPH soy-yogurts displayed greater firmness and higher water holding capacity than gels produced from conventional homogenized samples.

On the other hand, to enhance the resistance of probiotics during the product's entire shelf-life, new approaches are being taken by different researchers, such as the use of oxygen-impermeable containers, two-step fermentations and the incorporation of micronutrients into the matrices (peptides and/or amino-acids). Finally, the use of microencapsulation techniques has also been studied as a means of promoting the survival of the probiotic bacteria through the gastrointestinal tract (ability to resist gastric juices and bile) (Soccol et al., 2010).

\section{Conclusions}

The development of nut and cereal products, unfermented or fermented by means of probiotic bacteria, fully meets the current trend towards an increased consumer demand for healthier products, mainly because of the close relationship between the consumption of vegetable products and the prevention of cancer, atherosclerosis or inflammatory diseases, as has been claimed by some official American and European organizations. In this sense, the demand for and consumption of these products is expected to rise in the next few years, especially in that section of the population which is more aware of health issues. Moreover, and taking into account the low requirements for producing nuts and cereals, the high market potential of these products could be used in the not-to-far future to increase wealth in developing countries by implementing nut and cereals crops such as almonds and oats in noncultivated lands.

In the development of these products, some important technological deficiencies have been found, mainly related to the product's physical stability during its entire shelf-life. To this end, the optimization of processing techniques must be encouraged and more studies focusing on the microstructure and arrangement of the different components of the products after processing are needed in order to clarify and understand how to improve the appearance and texture of the final product. These studies would also allow a reduction in the amount of additives (hydrocolloids and/or emulsifiers) and thus reduce the economic costs. In the particular case of fermented products, the use of starter microorganisms which are able to both improve the quality (by synthesizing enhanced flavors and providing optimal textures) and exert health benefits for consumers (i.e. probiotics) is the main challenge to be faced in future studies. 
Nut and cereal vegetable milks $\mid 107$

Table 4: Main features and health benefits of the raw materials commercially used for producing vegetable milks

\begin{tabular}{|c|c|c|c|}
\hline $\begin{array}{l}\text { Raw } \\
\text { mate- } \\
\text { rial }\end{array}$ & Product features & Health benefits & References \\
\hline Almond & $\begin{array}{l}\S \text { Good source (arranged by im- } \\
\text { portance) of Vit. E, } \mathrm{K}, \mathrm{Mn}, \mathrm{Mg} \text {, } \\
\mathrm{Cu}, \mathrm{P} \text {, dietary fiber, riboflavin } \\
\text { and protein. }\end{array}$ & $\S$ Hypocholesterolemic benefits & $\begin{array}{l}\text { C.-Y. Chen et al., 2006; Hollis and } \\
\text { R. Mattes, 2007; Iacono, Lospal- } \\
\text { luti, Licastro, and Scalici, 2008; } \\
\text { Li et al., 2009; Mandalari, Nueno- } \\
\text { Palop, Bisignano, Wickham, and } \\
\text { Narbad, 2008; Rajaram, Connell, } \\
\text { and Sabate, 2010; Vinson and Cai, } \\
2012\end{array}$ \\
\hline (nut) & $\begin{array}{l}\S \text { Good lipid profile, mainly } \\
\text { MUFA } \\
\S \text { Important source of phytonu- } \\
\text { trients, mainly flavonoids and } \\
\text { proanthcyanidins. } \\
\S \text { Lactose-free; low digestible } \\
\text { carbohydrate } \\
\S \text { Cholesterol-free } \\
\S \text { High digestibility } \\
\S \text { Low GI } \\
\S \text { Low Na content }\end{array}$ & $\begin{array}{l}\S \text { Protective effect against CVD } \\
\S \text { Antioxidant properties } \\
\S \text { Electrolite balance contribu- } \\
\text { tion } \\
\text { § Glucorregulation properties } \\
\S \text { Prebiotic effect } \\
\S \text { Anti-inflammatory properties } \\
\S \text { Possible contribution to pro- } \\
\text { tect against some cancers, such } \\
\text { as colon cancer } \\
\text { § Suitable for celiacs and lactose } \\
\text { intolerants }\end{array}$ & \\
\hline Chestnut & $\begin{array}{l}\S \text { Good source of } \mathrm{K}, \mathrm{Mg}, \mathrm{Fe}, \mathrm{Ca} \text {, } \\
\mathrm{Mn}, \mathrm{Cu} \text {, dietary fiber, and pro- } \\
\text { tein rich in leucine and arginine. }\end{array}$ & $\S$ Hypocholesterolemic benefits & $\begin{array}{l}\text { O. Borges, Goncalves, de Carvalho, } \\
\text { Correia, and Silva, 2008; O. P. } \\
\text { Borges, Carvalho, Correia, and } \\
\text { Silva, 2007; De Vasconcelos, Ben- } \\
\text { nett, Rosa, and Ferreira-Cardoso, } \\
2010\end{array}$ \\
\hline (nut) & $\begin{array}{l}\S \text { Low-fat content } \\
\S \text { Good lipid profile, mainly } \\
\text { PUFA and followed by MUFA. } \\
\S \text { Important amounts folates, } \\
\text { thiamin and riboflavin } \\
\S \text { Important source of phenolic } \\
\text { compounds } \\
\S \text { Lactose-free; low available car- } \\
\text { bohydrate } \\
\S \text { Cholesterol-free } \\
\S \text { High digestibility } \\
\S \text { Low GI } \\
\S \text { Low Na content }\end{array}$ & $\begin{array}{l}\S \text { Protective effect against CVD } \\
\S \text { Antioxidant properties } \\
\S \text { Electrolite balance contribu- } \\
\text { tion } \\
\S \text { Glucorregulation properties } \\
\S \text { Prebiotic effect } \\
\S \text { Possible contribution in pro- } \\
\text { tection against some cancers, } \\
\text { such as colon cancer } \\
\S \text { Suitable for celiacs and lactose } \\
\text { intolerants }\end{array}$ & \\
\hline
\end{tabular}


$108 \mid$ Bernat et al.

Table 4 - Continued from previous page...

\begin{tabular}{|c|c|c|c|}
\hline $\begin{array}{l}\text { Raw } \\
\text { mate- } \\
\text { rial }\end{array}$ & Product features & Health benefits & References \\
\hline Hazelnut & $\begin{array}{l}\S \text { Good source of Vit. E, K, } \\
\text { Fe, Ca, Mg, Zn, dietary fiber, } \\
\text { and protein rich in arginine and } \\
\text { leucine. }\end{array}$ & $\S$ Hypocholesterolemic benefits & $\begin{array}{l}\text { Alasalvar, Shahidi, Liyanapathi- } \\
\text { rana, and Ohshima, 2003; Durak } \\
\text { et al., 1999; Koksal, Artik, Simsek, } \\
\text { and Gunes, 2006; Li et al., 2009; } \\
\text { Mercanligil et al., 2007; Ozdemir et } \\
\text { al., 2001, Tey et al., 2011 }\end{array}$ \\
\hline (nut) & 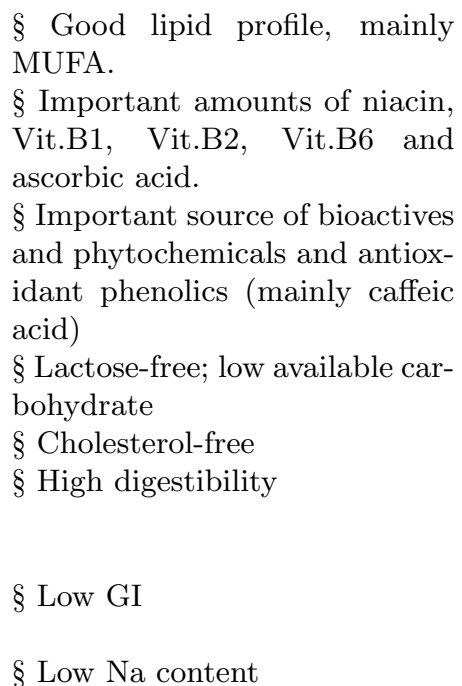 & $\begin{array}{l}\S \text { Protective effect against CVD } \\
\S \text { Antioxidant properties } \\
\S \text { Electrolite balance contribu- } \\
\text { tion } \\
\S \text { Glucorregulation properties } \\
\S \text { Prebiotic effect } \\
\S \text { Possible contribution protec- } \\
\text { tion against some cancers, such } \\
\text { as colon or prostate cancers } \\
\S \text { Suitable for celiacs and lactose } \\
\text { intolerants }\end{array}$ & 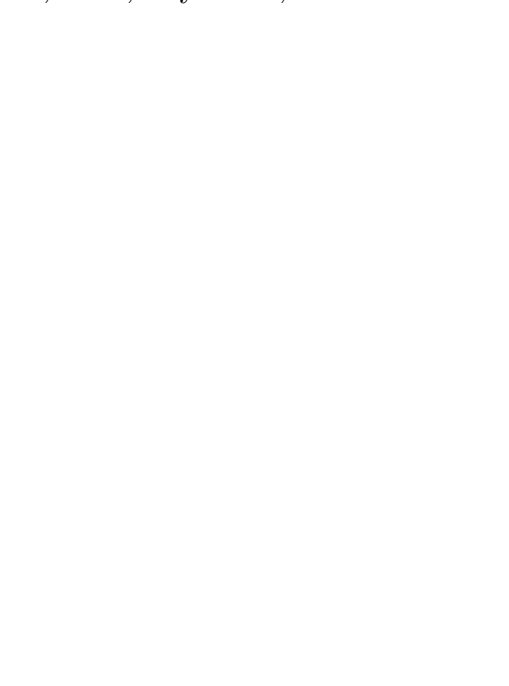 \\
\hline Walnuts & $\begin{array}{l}\S \text { Good source of } \mathrm{K}, \mathrm{P}, \mathrm{Mg}, \mathrm{Fe} \text {, } \\
\mathrm{Mn}, \mathrm{Cu}, \mathrm{Zn} \text {, dietary fiber, and } \\
\text { protein rich in arginine. }\end{array}$ & $\S$ Hypocholesterolemic benefits & $\begin{array}{l}\text { Almario, Vonghavaravat, Wong, } \\
\text { and Kasim-Karakas, 2001; Banel } \\
\text { and F. B. Hu, 2009; Chisholm } \\
\text { et al., 1998; Elaine and Feldman, } \\
\text { 2002; Li et al., 2009; Sze-Tao and } \\
\text { Sathe, 2000; Vinson and Cai, 2012; } \\
\text { Zambón et al., } 2000\end{array}$ \\
\hline (nut) & $\begin{array}{l}\S \text { Good lipid profile, mainly } \\
\text { PUFA (linoleic and g-linolenic } \\
\text { acids). } \\
\S \text { Appreciable amounts of Vit.E, } \\
\text { niacin, thiamin, riboflavin and } \\
\text { folic acid. } \\
\text { § Important source of bioactives } \\
\text { and phytochemicals } \\
\text { \& Cholesterol-free } \\
\S \text { High digestibility } \\
\S \text { Low GI } \\
\S \text { Low Na content }\end{array}$ & $\begin{array}{l}\S \text { Protective effect against CVD } \\
\S \text { Antioxidant properties } \\
\S \text { Electrolite balance contribu- } \\
\text { tion } \\
\S \text { Glucorregulation properties } \\
\S \text { Prebiotic effect } \\
\S \text { Anti-inflammatory properties } \\
\S \text { Possible contribution in pro- } \\
\text { tection against some cancers, } \\
\text { such as colon or prostate can- } \\
\text { cers } \\
\S \text { Suitable for celiacs and lactose } \\
\text { intolerants }\end{array}$ & \\
\hline
\end{tabular}


Nut and cereal vegetable milks $\mid 109$

Table 4 - Continued from previous page...

\begin{tabular}{|c|c|c|c|}
\hline $\begin{array}{l}\text { Raw } \\
\text { mate- } \\
\text { rial }\end{array}$ & Product features & Health benefits & References \\
\hline Amaranth & $\begin{array}{l}\S \text { Good source of Vit.E, Ca, Mg, } \\
\text { K, P, Fe and Zn }\end{array}$ & $\S$ Hypocholesterolemic benefits & $\begin{array}{l}\text { Alvarez-Jubete, Arendt, } \text { and } \\
\text { Gallagher, 2010; Caselato-Sousa } \\
\text { and Amaya-Farfan, 2012; Mar- } \\
\text { cone, Kakuda, and Yada, 2003; } \\
\text { Sanz-Penella, Wronkowska, Soral- } \\
\text { Smietana, and Haros, } 2013\end{array}$ \\
\hline (cereal) & $\begin{array}{l}\S \text { High content in both soluble } \\
\text { and insoluble fiber } \\
\S \text { Good lipid profile, mainly } \\
\text { PUFA (linoleic acid), followed } \\
\text { by MUFA (oleic acid) } \\
\S \text { Good protein source rich in ly- } \\
\text { sine and methionine } \\
\S \text { High phytosterol content, } \\
\text { mainly b-sitosterol } \\
\S \text { High levels of tocotrienols and } \\
\text { squalene (cholesterol-lowering } \\
\text { comp.) } \\
\S \text { Important amounts of Vit.C, } \\
\text { riboflavin and niacin. } \\
\S \text { Important source flavonoids } \\
\text { and phenolic compounds. } \\
\S \text { Source of Lunasin (antitu- } \\
\text { moral peptide) } \\
\S \text { Lactose-free; low available car- } \\
\text { bohydrate } \\
\S \text { Gluten-free } \\
\S \text { Cholesterol-free } \\
\S \text { High digestibility } \\
\S \text { Low GI }\end{array}$ & $\begin{array}{l}\S \text { Electrolite balance contribu- } \\
\text { tion } \\
\S \text { Glucorregulation properties } \\
\S \text { Prebiotic effect } \\
\S \text { Possible contribution in pro- } \\
\text { tection against some cancers } \\
\text { such as colon cancer } \\
\S \text { Suitable for celiacs, diabetics } \\
\text { and lactose intolerants } \\
\S \text { Antitumor effects } \\
\S \text { Anti-inflammatory properties } \\
\S \text { Anti-anemic effects }\end{array}$ & \\
\hline Barley & $\begin{array}{l}\S \text { Good source of } \mathrm{Ca}, \mathrm{Mg}, \mathrm{K}, \mathrm{P} \text {, } \\
\text { Fe and } \mathrm{Zn}\end{array}$ & $\S$ Hypocholesterolemic benefits & $\begin{array}{l}\text { AbuMweis, Jew, and Ames, 2010; } \\
\text { Ames and Rhymer, 2008; Baik and } \\
\text { Ullrich, 2008; K. D. Kaur et al., } \\
\text { 2011; Thondre, Ryan, and Henry, } \\
\text { 2011; J. L. Ward et al., 2008. }\end{array}$ \\
\hline (cereal) & $\begin{array}{l}\S \text { High content in dietary fiber, } \\
\text { rich in b -glucans } \\
\S \text { Good lipid profile, mainly } \\
\text { PUFA } \\
\S \text { Good protein source rich in ly- } \\
\text { sine } \\
\S \text { Important source of to- } \\
\text { copherols and tocotrienols } \\
\text { (cholesterol-lowering comp.) } \\
\S \text { Important amounts of group } \\
\text { B vitamins, mainly nicacin, ri- } \\
\text { boflavin folate and thiamin. }\end{array}$ & $\begin{array}{l}\S \text { Protective effect against CVD } \\
\S \text { Antioxidant properties } \\
\S \text { Electrolite balance contribu- } \\
\text { tion } \\
\S \text { Glucorregulation properties }\end{array}$ & \\
\hline
\end{tabular}


$110 \mid$ Bernat et al.

Table 4 - Continued from previous page...

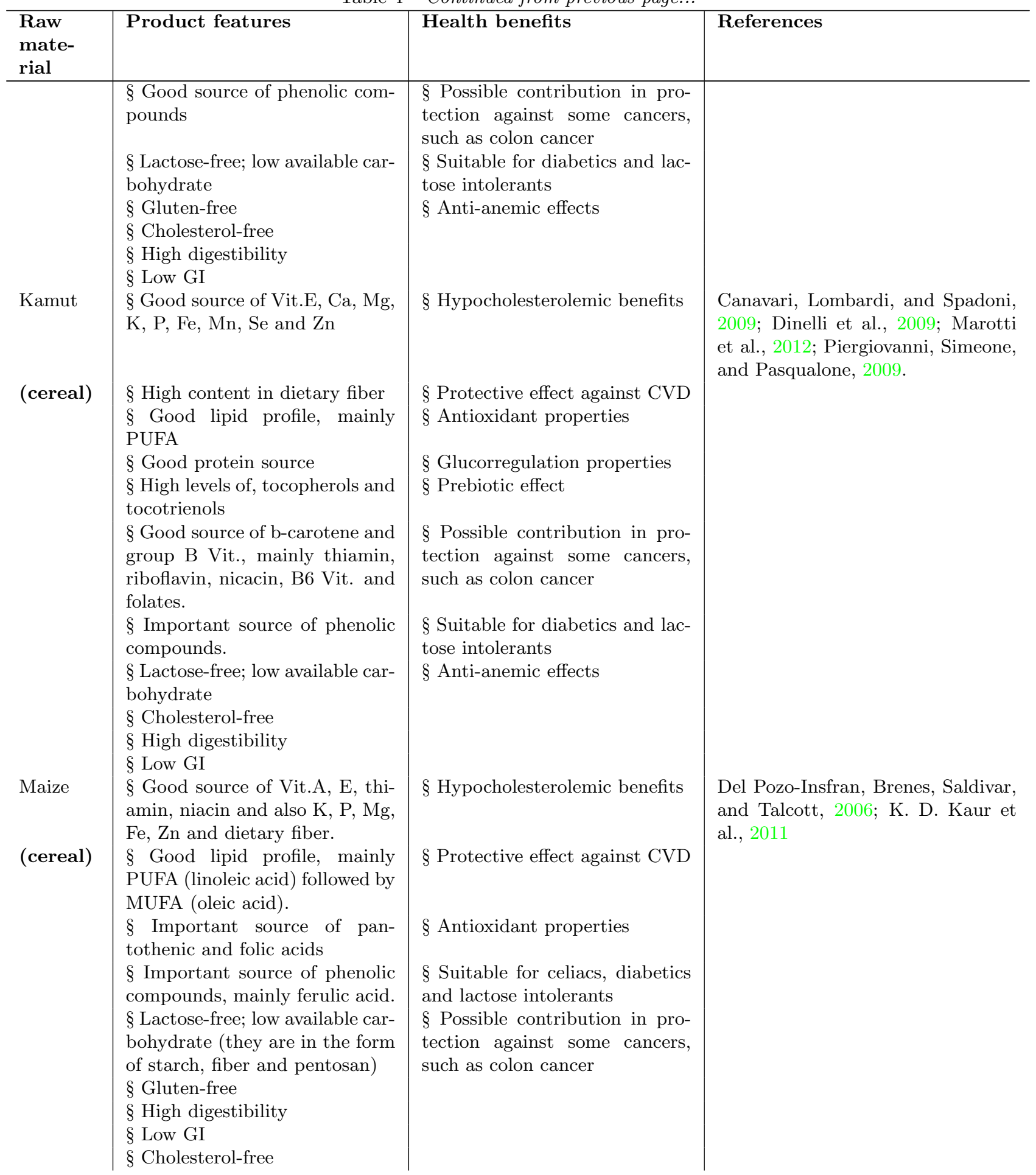


Nut and cereal vegetable milks $\mid 111$

Table 4 - Continued from previous page...

\begin{tabular}{|c|c|c|c|}
\hline $\begin{array}{l}\text { Raw } \\
\text { mate- } \\
\text { rial }\end{array}$ & Product features & Health benefits & References \\
\hline Millet & $\begin{array}{l}\text { § Good source of } \mathrm{Ca}, \mathrm{Mg}, \mathrm{K}, \mathrm{P} \text {, } \\
\text { Fe Zn }\end{array}$ & $\S$ Hypocholesterolemic benefits & $\begin{array}{l}\text { Chandrasekara and Shahidi, 2011; } \\
\text { Devi, Vijayabharathi, Sathyabama, } \\
\text { Malleshi, and Priyadarisini, 2011; } \\
\text { Hegde, Rajasekaran, and Chandra, } \\
\text { 2005; Léder, 2004; K. D. Kaur et } \\
\text { al., 2011; }\end{array}$ \\
\hline (cereal) & $\begin{array}{l}\S \text { High content in insoluble di- } \\
\text { etary fiber } \\
\S \text { Good lipid profile, mainly } \\
\text { PUFA (linoleic acid), followed } \\
\text { by MUFA } \\
\S \text { Important amounts of group } \\
\text { B vitamins, mainly thiamin, ri- } \\
\text { boflavin, folate and niacin. } \\
\S \text { Good source of phenolic com- } \\
\text { pounds } \\
\S \text { Lactose-free; low available car- } \\
\text { bohydrate } \\
\S \text { Gluten-free } \\
\S \text { Cholesterol-free } \\
\S \text { Low GI }\end{array}$ & $\begin{array}{l}\S \text { Protective effect against CVD } \\
\S \text { Antioxidant properties } \\
\S \text { Glucorregulation properties } \\
\S \text { Prebiotic effect } \\
\S \text { Possible contribution in pro- } \\
\text { tection against some cancers, } \\
\text { such as colon cancer } \\
\S \text { Suitable for celiacs, diabetics } \\
\text { and lactose intolerants } \\
\S \text { Anti-anemic effects }\end{array}$ & \\
\hline Oat & $\begin{array}{l}\S \text { Good source of Vit.E, Ca, Mg, } \\
\mathrm{K}, \mathrm{P}, \mathrm{Fe}, \mathrm{Cu} \text { and } \mathrm{Zn}\end{array}$ & 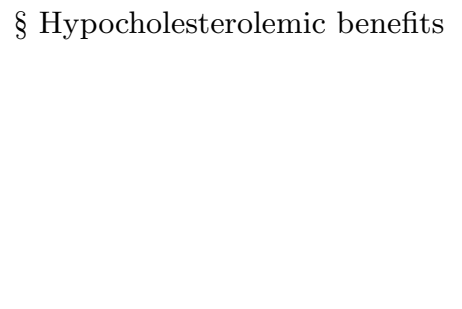 & $\begin{array}{l}\text { Biel, Bobko, and Maciorowski, } \\
\text { 2009; Daou and Zhang, 2012; Jing } \\
\text { and X. Hu, 2012; K. D. Kaur et al., } \\
\text { 2011; Kemppainen, Heikkinen, Ris- } \\
\text { tikankare, Kosma, and Julkunen, } \\
\text { 2009; Butt, Tahir-Nadeem, Khan, } \\
\text { Shabir, and Butt, 2008; Thompson, } \\
\text { 2003; J. L. Ward et al., 2008; }\end{array}$ \\
\hline (cereal) & $\begin{array}{l}\S \text { High content in dietary fiber, } \\
\text { rich in b-glucans } \\
\S \text { Good lipid profile, mainly } \\
\text { PUFA } \\
\S \text { Good protein source rich in } \\
\text { lsulfur aminoacids, such as me- } \\
\text { thionine and cystine (essential } \\
\text { aminoacids) } \\
\S \text { Important amounts of group } \\
\text { B vitamins, mainly nicacin, ri- } \\
\text { boflavin and thiamin. } \\
\S \text { Good source of tocopherols } \\
\text { and phenolic compounds } \\
\S \text { Lactose-free; low available car- } \\
\text { bohydrate } \\
\S \text { Gluten-free }\end{array}$ & $\begin{array}{l}\S \text { Protective effect against CVD } \\
\S \text { Antioxidant properties } \\
\S \text { Electrolite balance contribu- } \\
\text { tion } \\
\S \text { Glucorregulation properties } \\
\S \text { Prebiotic effect } \\
\S \text { Possible contribution in pro- } \\
\text { tection against some cancers, } \\
\text { such as colon cancer } \\
\S \text { Suitable for celiac, diabetics } \\
\text { and lactose intolerants }\end{array}$ & \\
\hline
\end{tabular}


Table 4 - Continued from previous page...

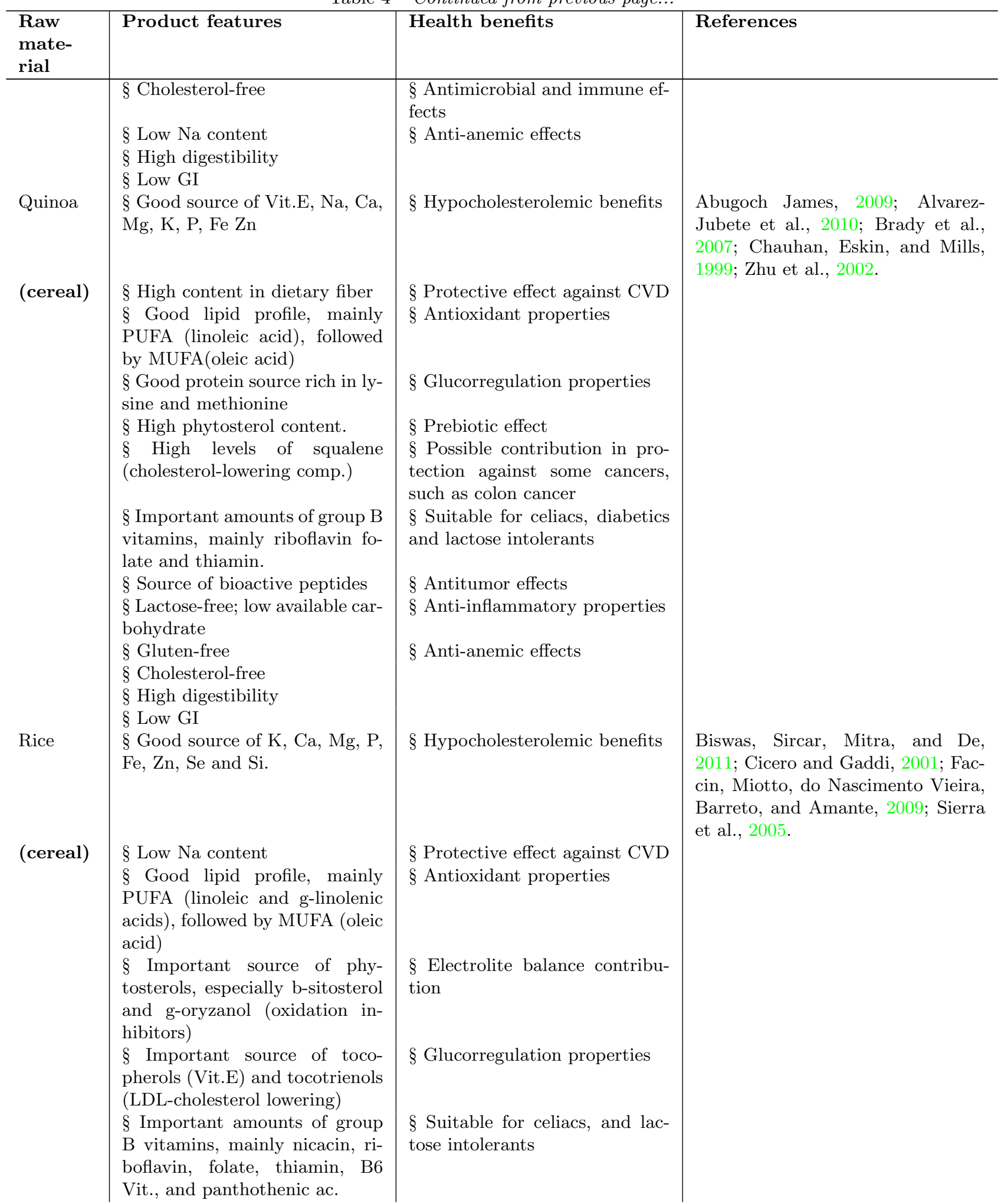


Nut and cereal vegetable milks $\mid 113$

Table 4 - Continued from previous page...

\begin{tabular}{|c|c|c|}
\hline $\begin{array}{l}\text { Raw } \\
\text { mate- } \\
\text { rial }\end{array}$ & Product features & Health benefits \\
\hline Sesame & $\begin{array}{l}\S \text { Good source of phenolic com- } \\
\text { pounds } \\
\S \text { Lactose-free } \\
\text { § Gluten-free } \\
\text { § Cholesterol-free } \\
\text { § High digestibility } \\
\text { § Good source of Vit. E Ca, Mg, } \\
\mathrm{K}, \mathrm{P}, \mathrm{Fe}, \mathrm{Zn} \text { and } \mathrm{Cu} \text {. }\end{array}$ & $\begin{array}{l}\S \text { Antitumor effects } \\
\S \text { Anti-inflammatory properties. }\end{array}$ \\
\hline (cereal) & 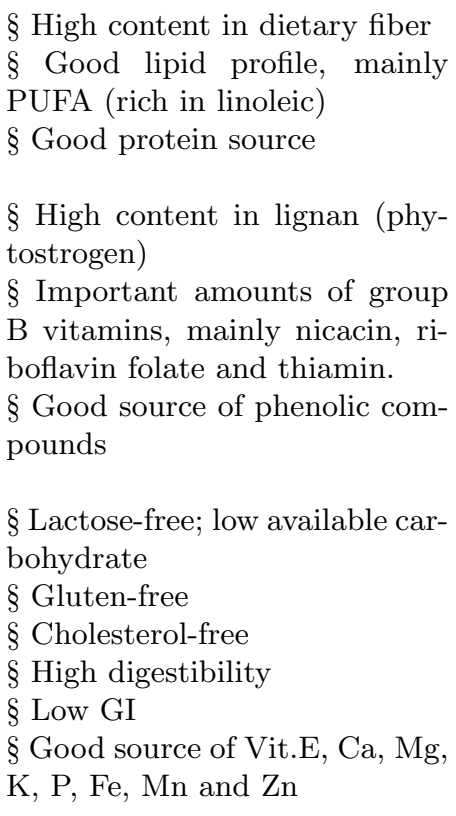 & $\begin{array}{l}\S \text { Protective effect against CVD } \\
\S \text { Antioxidant properties } \\
\S \text { Electrolite balance contribu- } \\
\text { tion } \\
\S \text { Glucorregulation properties } \\
\S \text { Prebiotic effect }\end{array}$ \\
\hline (cereal) & $\begin{array}{l}\S \text { High content in dietary fiber } \\
\S \text { Low Na content } \\
\S \text { Good lipid profile, mainly } \\
\text { PUFA (linoleic acid), followed } \\
\text { by MUFA (oleic acid) } \\
\text { § Good protein source } \\
\S \text { High levels of, tocopherols and } \\
\text { tocotrienols } \\
\S \text { Good source of group B } \\
\text { Vit., mainly thiamin, riboflavin, } \\
\text { nicacin, B6 Vit. and folates. } \\
\S \text { Important source of phenolic } \\
\text { compounds. } \\
\S \text { Lactose-free; low available car- } \\
\text { bohydrate }\end{array}$ & $\begin{array}{l}\S \text { Protective effect against CVD } \\
\S \text { Antioxidant properties } \\
\S \text { Electrolite balance contribu- } \\
\text { tion } \\
\S \text { Glucorregulation properties } \\
\S \text { Prebiotic effect } \\
\S \text { Possible contribution in pro- } \\
\text { tection against some cancers, } \\
\text { such as colon cancer } \\
\S \text { Suitable for diabetics and lac- } \\
\text { tose intolerants } \\
\S \text { Anti-anemic effects }\end{array}$ \\
\hline
\end{tabular}

Cooney, Custer, Okinaka, and Franke, 2001; Sirato-Yasumoto, Katsuta, Okuyama, Takahashi, and Ide, 2001; Wu, Kang, Wang, Jou, and Wang, 2006;

J. L. Ward et al., 2008; Zielinski, Ceglinska, and Michalska, 2008; Marques et al., 2007, RuibalMendieta et al., 2005; Ranhotra, Gelroth, Glaser, and Lorenz, 1996. 
$114 \mid$ Bernat et al.

Table 4 - Continued from previous page...

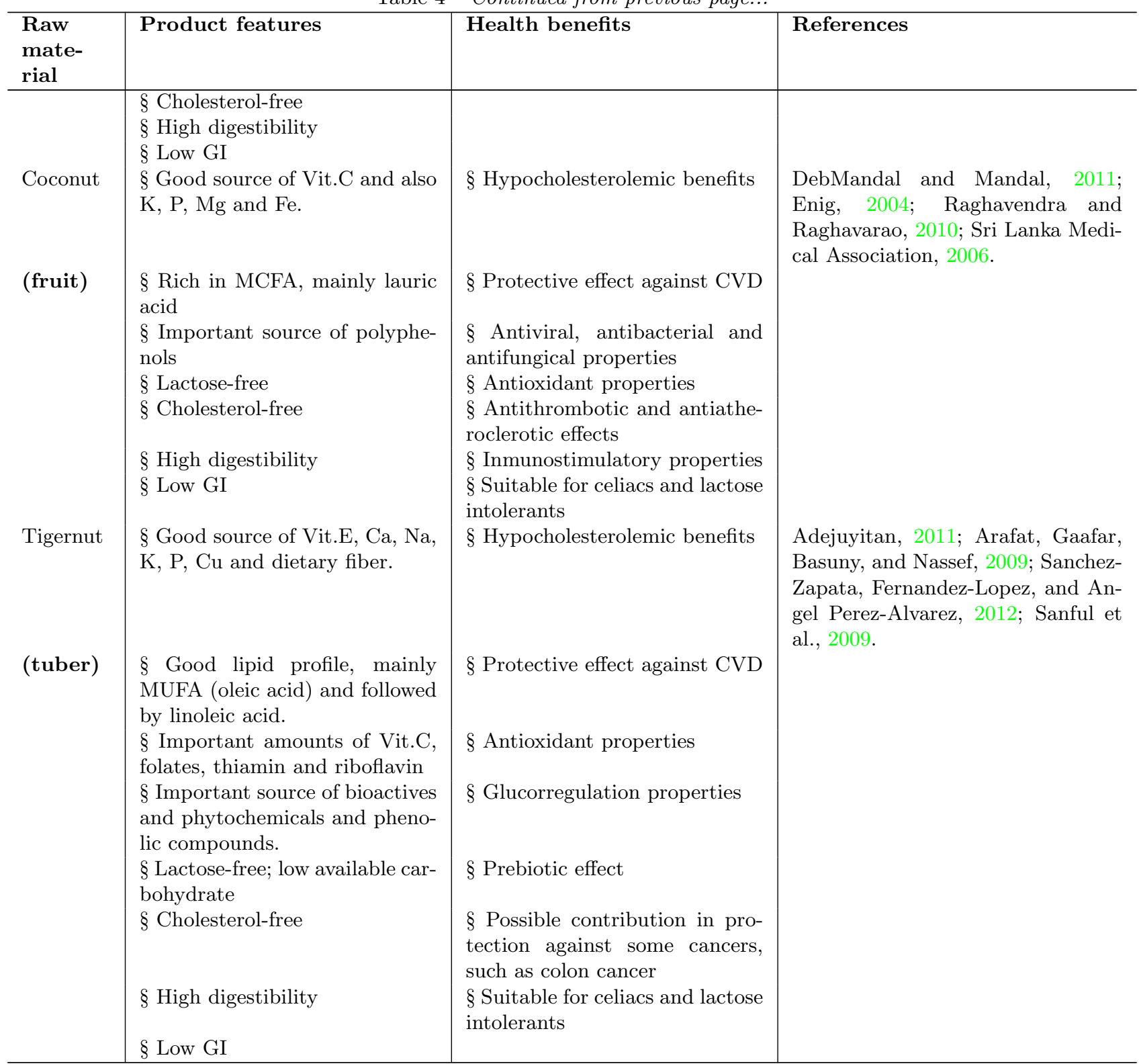


Nut and cereal vegetable milks |115

\section{References}

Abugoch James, L. E. (2009). Chapter 1 quinoa (chenopodium quinoa willd.) Advances in Food and Nutrition Research, 1-31. doi:10. 1016/s1043-4526(09)58001-1

AbuMweis, S. S., Jew, S., \& Ames, N. P. (2010). Beta-glucan from barley and its lipidlowering capacity: a meta-analysis of randomized, controlled trials. European Journal of Clinical Nutrition, 64(12), 14721480. doi:10.1038/ejcn.2010.178

Adejuyitan, J. (2011). Tigernut processing: its food uses and health benefits. American Journal of Food Technology, 6(3), 197-201. doi:10.3923/ajft.2011.197.201

Agostoni, C., Bresson, J., Tait, S. F., Flynn, A., Golly, I., Korhonen, H., ... Martin, A., et al. (2011). Scientific opinion on the substantiation of health claims related to nuts and essential fatty acids (omega-3/omega6 ) in nut oil (id 741, 1129, 1130, 1305, 1407) pursuant to article 13 (1) of regulation (ec) no 1924/2006. EFSA journal, 9(4), 20321.

Akalin, A. S., Tokusoglu, O., Gonc, S., \& Aycan, S. (2007). Occurrence of conjugated linoleic acid in probiotic yoghurts supplemented with fructooligosaccharide. International Dairy Journal, 17(9), 1089-1095. doi:10.1016/j.idairyj.2007.02.005

Alasalvar, C., Shahidi, F., Liyanapathirana, C., \& Ohshima, T. (2003). Turkish tombul hazelnut (corylus avellana 1.). 1. compositional characteristics. Journal of Agricultural and Food Chemistry, 51(13), 37903796. doi:10.1021/jf0212385

Almario, R. U., Vonghavaravat, V., Wong, R., \& Kasim-Karakas, S. E. (2001). Effects of walnut consumption on plasma fatty acids and lipoproteins in combined hyperlipidemia. The American Journal of Clinical Nutrition, 74(1), 72-79. eprint: http: / / ajcn . nutrition . org / content / 74/1/ 72 . full.pdf+html. Retrieved from http://ajcn. nutrition.org/content/74/1/72.abstract

Alvarez-Jubete, L., Arendt, E. K., \& Gallagher, E. (2010). Nutritive value of pseudocereals and their increasing use as functional gluten-free ingredients. Trends in Food Sci- ence \& Technology, 21(2), 106-113. doi:10. 1016/j.tifs.2009.10.014

Ames, N. P. \& Rhymer, C. R. (2008). Issues surrounding health claims for barley. The Journal of Nutrition, 138(6), 1237S-1243S. eprint: http: / / jn. nutrition.org / content/ 138/6/1237S.full.pdf+html

Angelov, A., Gotcheva, V., Kuncheva, R., \& Hristozova, T. (2006). Development of a new oat-based probiotic drink. International Journal of Food Microbiology, 112(1), 7580. doi:http : / / dx . doi . org / $10.1016 / \mathrm{j}$. ijfoodmicro.2006.05.015

Arafat, S., Gaafar, A., Basuny, A., \& Nassef, S. (2009). Chufa tubers (cyperus esculentus 1.). as a new source of food. World Applied Sciences Journal, 7(3), 151-156. Retrieved from http://www.idosi.org/wasj/wasj7(2) /4.pdf.

Baik, B.-K. \& Ullrich, S. E. (2008). Barley for food: characteristics, improvement, and renewed interest. Journal of Cereal Science, 48(2), 233-242. doi:10.1016/j.jcs.2008.02. 002

Banel, D. K. \& Hu, F. B. (2009). Effects of walnut consumption on blood lipids and other cardiovascular risk factors: a meta-analysis and systematic review. American Journal of Clinical Nutrition, 90(1), 56-63. doi:10. 3945/ajcn.2009.27457

Bernat, N., Chafer, M., A., C., \& GonzálezMartínez, C. (2011). Effect of ultra-high pressure homogenization. Effect of ultrahigh pressure homogenization and heat treatment on physicochemical properties of almond beverages. In T. P.S., K. V.T., \& S. G.D. (Eds.), Proceedings of the $11^{\text {th }}$ International Congress on Engineering \& Food (ICEF11). (p. 6). Paper presented at $11^{\text {th }}$ International Congress on Engineering \& Food, held at Athens. Athens: ICEF.

Biel, W., Bobko, K., \& Maciorowski, R. (2009). Chemical composition and nutritive value of husked and naked oats grain. Journal of Cereal Science, 49(3), 413-418. doi:10. 1016/j.jcs.2009.01.009

Biswas, S., Sircar, D., Mitra, A., \& De, B. (2011). Phenolic constituents and antioxidant properties of some varieties of indian 
rice. Nutrition \&3 Food Science, 41(2), 123135. doi:10.1108/00346651111117391

Blaiotta, G., Di Capua, M., Coppola, R., \& Aponte, M. (2012). Production of fermented chestnut purees by lactic acid bacteria. International Journal of Food Microbiology, 158(3), 195-202. doi:10.1016/j . ijfoodmicro.2012.07.012

Boonyaratanakornkit, M. \& Wongkhalaung, C. (2000). Development of a yoghurt-type product from saccharified rice. Kasetsart Journal, Natural Sciences, 34(1), 107-116. Retrieved from http://kasetsartjournal.ku. ac.th/kuj_files/2008/A0804280948236253. pdf

Borges, O. P., Carvalho, J. S., Correia, P. R., \& Silva, A. P. (2007). Lipid and fatty acid profiles of castanea sativa mill. chestnuts of 17 native portuguese cultivars. Journal of Food Composition and Analysis, 20(2), 8089. doi:10.1016/j.fca.2006.07.008

Borges, O., Goncalves, B., de Carvalho, J. L. S., Correia, P., \& Silva, A. P. (2008). Nutritional quality of chestnut (castanea sativa mill.) cultivars from portugal. Food Chemistry, 106(3), 976-984. doi:10.1016/ j . foodchem.2007.07.011

Bosnea, L. A., Kourkoutas, Y., Albantaki, N., Tzia, C., Koutinas, A. A., \& Kanellaki, M. (2009). Functionality of freeze-dried 1. casei cells immobilized on wheat grains. LWT-food Science And Technology, 42(10), 1696-1702. doi:10.1016/j.lwt.2009.05.011

Brady, K., Ho, C.-T., Rosen, R. T., Sang, S., \& Karwe, M. V. (2007). Effects of processing on the nutraceutical profile of quinoa. Food Chemistry, 100(3), 1209-1216. doi:10. 1016/j.foodchem.2005.12.001

Burdock, G. A. \& Carabin, I. G. (2008). Breaking down the barriers to functional foods, nutraceuticals and claims. Elsevier. doi:10. 1016/B978-012373901-8.00007-X

Butt, M. S., Tahir-Nadeem, M., Khan, M. K. I., Shabir, R., \& Butt, M. S. (2008). Oat: unique among the cereals. European Journal of Clinical Nutrition, 47(2), 68-79. doi:10.1007/s00394-008-0698-7

Canavari, M., Lombardi, P., \& Spadoni, R. (2009). Evaluation of the potential interest of italian retail distribution chains for kamut-based products. Journal of Food Products Marketing, 16(1), 39-59. Retrieved from http:// ageconsearch. umn . edu/bitstream/7854/1/cp070036.pdf

Carlson, J. J., Eisenmann, J. C., Norman, G. J., Ortiz, K. A., \& Young, P. C. (2011). Dietary fiber and nutrient density are inversely associated with the metabolic syndrome in us adolescents. Journal of the American Dietetic Association, 111(11), 1688-1695. doi:10.1016/j.jada.2011.08.008

Caselato-Sousa, V. M. \& Amaya-Farfan, J. (2012). State of knowledge on amaranth grain: a comprehensive review. Journal of Food Science, 77(4), R93-R104. doi:10 . 1111/j.1750-3841.2012.02645.x

Chan, J. M., Wang, F., \& Holly, E. A. (2007). Whole grains and risk of pancreatic cancer in a large population-based case-control study in the san francisco bay area, california. American Journal of Epidemiology, 166 (10), 1174-1185. doi:10.1093/aje/ kwm194

Chandrasekara, A. \& Shahidi, F. (2011). Bioactivities and antiradical properties of millet grains and hulls. Journal of Agricultural and Food Chemistry, 59(17), 95639571. doi:10.1021/jf201849d

Charalampopoulos, D. [D], Pandiella, S., \& Webb, C. (2002). Growth studies of potentially probiotic lactic acid bacteria in cereal-based substrates. Journal of Applied Microbiology, 92(5), 851-859. doi:10.1046/ j.1365-2672.2002.01592.x

Charalampopoulos, D. [Dimitris] \& Pandiella, S. S. (2010). Survival of human derived lactobacillus plantarum in fermented cereal extracts during refrigerated storage. $L W T$ food Science And Technology, 43(3), 431435. doi:10.1016/j.lwt.2009.09.006

Chauhan, G., Eskin, N., \& Mills, P. (1999). Effect of saponin extraction on the nutritional quality of quinoa (chenopodium quinoa willd.) proteins. Journal of Food Science and Technology, 36(2), 123-126. Retrieved from http://cat.inist.fr/

Chen, C.-Y., Lapsley, K., \& Blumberg, J. (2006). A nutrition and health perspective on almonds. Journal of the Science of Food 
Nut and cereal vegetable milks |117

and Agriculture, 86(14), 2245-2250. doi:10. $1002 /$ jsfa. 2659

Chen, C., Milbury, P., Kwak, H., Collins, F., Samuel, P., \& Blumberg, J. (2004). Avenenthramines and phenolic acids from oats are bioavailable and act synergistically with vit $\mathrm{c}$ to enhance hamster and human ldl resistance to oxidation. Journal of $\mathrm{Nu}$ trition, 134(6), 1459-1466. Retrieved from http://jn.nutrition.org/

Chiewchan, N., Phungamngoen, C., \& Siriwattanayothin, S. (2006). Effect of homogenizing pressure and sterilizing condition on quality of canned high fat coconut milk. Journal of Food Engineering, 73(1), 38-44. doi:10.1016/j.jfoodeng.2005.01.003

Chisholm, A., Mann, J., Skeaff, M., Frampton, C., Sutherland, W., Duncan, A., \& Tiszavari, S. (1998). A diet rich in walnuts favourably influences plasma fatty acid profile in moderately hyperlipidaemic subjects. European Journal of Clinical $\mathrm{Nu}$ trition, 52(1), 12-16. doi:10.1038/sj.ejcn. 1600507

Cicero, A. \& Gaddi, A. (2001). Rice bran oil and gamma-oryzanol in the treatment of hyperlipoproteinaemias and other conditions. Phytotherapy Research, 15(4), 277289. doi:10.1002/ptr.907

Coda, R., Rizzello, C. G., \& Gobbetti, M. (2010). Use of sourdough fermentation and pseudocereals and leguminous flours for the making of a functional bread enriched of gamma-aminobutyric acid (gaba). International Journal of Food Microbiology, 137(23), 236-245. doi:10.1016/j . ijfoodmicro . 2009.12.010

Coniglio, R. (2008). Frutos secos: el cultivo del almendro. "una actividad alternativa". Revista Agromensajes, 25. Retrieved from http: / / www.fcagr.unr.edu.ar/Extension/ Agromensajes/25/4AM25.htm

Cooney, R., Custer, L., Okinaka, L., \& Franke, A. (2001). Effects of dietary sesame seeds on plasma tocopherol levels. Nutrition and Cancer-an International Journal, 39(1), 66-71. doi:10.1207/S15327914nc391\_9

Correa, S. B. M., Castro, I. A., \& Saad, S. M. I. (2008). Probiotic potential and sensory properties of coconut flan supplemented with lactobacillus paracasei and bifidobacterium lactis. International Journal of Food Science and Technology, 43(9), 1560-1568. doi:10.1111/j.1365-2621.2007.01585.x

CRDO: Consejo Regulador de la Denominación de Origen Chufa de Valencia. (2012). Effects of ultra-high pressure homogenization on microbial and physicochemical shelf life of milk. Horchata de Chufa, Elaboración. Retrieved from http : / / www . chufadevalencia . org / ver / 18 / Elaboraci \% C3\%83\%C2\%B3n.html

Cruz, N. S., Capellas, M., Jaramillo, D. P., Trujillo, A. J., Guamis, B., \& Ferragut, V. (2009). Soymilk treated by ultra highpressure homogenization: acid coagulation properties and characteristics of a soyyogurt product. Food Chemistry, 23(2), 490-496. doi:10.1016/j. foodhyd.2008.03. 010

Cruz, N., Capellas, M., Hernandez, M., Trujillo, A. J., Guamis, B., \& Ferragut, V. (2007). Ultra high pressure homogenization of soymilk: microbiological, physicochemical and microstructural characteristics. Food Research International, 40(6), 725-732. doi:10.1016/j.foodres.2007.01.003

Cui, X.-H., Chen, S.-J., Wang, Y., \& Han, J.-R. (2013). Fermentation conditions of walnut milk beverage inoculated with kefir grains. LWT-Food Science and Technology, 50(1), 349-352. doi:10.1016/j.lwt.2012.07.043

Daou, C. \& Zhang, H. (2012). Oat beta-glucan: its role in health promotion and prevention of diseases. Comprehensive Reviews in Food Science and Food Safety, 11(4), 355-365. doi:10.1111/j.1541-4337.2012.00189.x

De Vasconcelos, M. C. B. M., Bennett, R. N., Rosa, E. A. S., \& Ferreira-Cardoso, J. V. (2010). Composition of european chestnut (castanea sativa mill.) and association with health effects: fresh and processed products. Journal of the Science of Food and Agriculture, 90(10), 1578-1589. doi:10. $1002 /$ jsfa. 4016

de Munter, J. S. L., Hu, F. B., Spiegelman, D., Franz, M., \& van Dam, R. M. (2007). Whole grain, bran, and germ intake and risk of type 2 diabetes: a prospective cohort study and systematic review. Plos 
medicine, 4(8), 1385-1395. doi:10.1371/ journal.pmed.0040261

DebMandal, M. \& Mandal, S. (2011). Coconut (Cocos nucifera L.: Arecaceae): in health promotion and disease prevention. Asian Pacific Journal of Tropical Medicine, 4(3), 241-247.

Del Pozo-Insfran, D., Brenes, C., Saldivar, S., \& Talcott, S. (2006). Polyphenolic and antioxidant content of white and blue corn (zea mays 1.) products. Food Research International, 39(6), 696-703. doi:10.1016/j. foodres.2006.01.014

Devi, P. B., Vijayabharathi, R., Sathyabama, S., Malleshi, N. G., \& Priyadarisini, V. B. (2011). Health benefits of finger millet (eleusine coracana 1.) polyphenols and dietary fiber: a review. Journal of Food Science and Technology. doi:10.1007/s13197011-0584-9

Dewanto, V., Wu, X., \& Liu, R. (2002). Processed sweet corn has higher antioxidant activity. Journal of Agricultural and Food Chemistry, 50(17), 4959-4964. doi:10 . 1021/jf0255937

Dinelli, G., Segura Carretero, A., Di Silvestro, R., Marotti, I., Fu, S., Benedettelli, S., ... Fernandez Gutierrez, A. (2009). Determination of phenolic compounds in modern and old varieties of durum wheat using liquid chromatography coupled with time-of-flight mass spectrometry. Journal of Chromatography A, 1216(43), 72297240. doi:10.1016/j.chroma.2009.08.041

Durak, I., Koksal, I., Kacmaz, M., Buyukkocak, S., Cimen, B., \& Ozturk, H. (1999). Hazelnut supplementation enhances plasma antioxidant potential and lowers plasma cholesterol levels. Clinica Chimica Acta, 284(1), 113-115. doi:10 . 1016 / S0009 8981(99)00066-2

Dykes, L. \& Rooney, L. W. (2006). Sorghum and millet phenols and antioxidants. Journal of Cereal Science, 44(3), 236-251. doi:10. $1016 /$ j.jcs.2006.06.007

Egert, S., Kratz, M., Kannenberg, F., Fobker, M., \& Wahrburg, U. (2011). Effects of high-fat and low-fat diets rich in monounsaturated fatty acids on serum lipids, ldl size and indices of lipid peroxidation in healthy non-obese men and women when consumed under controlled conditions. European Journal of Clinical Nutrition, 50(1), 71-79. doi:10.1007/s00394-010-0116-9

Elaine, B. \& Feldman, M. (2002). The scientific evidence for a beneficial health relationship between walnuts and coronary heart disease. Journal of Nutrition, 132(5), 1062S1101S. Retrieved from http://jn.nutrition. org/

Enig, M. G. (2004). Coconut: in support of good health in the 21 st century. In F.A.C.N. Source. Retrieved from http://coconutoil. com/coconut_oil_21st_century/

Erra, S. (2012). Process for the preparation of a beverage from nuts. EP Patent 2,342,980 EP2342980A1. Google Patents. Retrieved from https: / / www.google.com / patents / $\mathrm{EP} 2342980 \mathrm{~B} 1 ? \mathrm{cl}=\mathrm{en}$

Esmaillzadeh, A., Mirmiran, P., \& Azizi, F. (2005). Whole-grain consumption and the metabolic syndrome: a favorable association in tehranian adults. European Journal of Clinical Nutrition, 59(3), 353-362. doi:10.1038/sj.ejcn.1602080

Faccin, G. L., Miotto, L. A., do Nascimento Vieira, L., Barreto, P. L. M., \& Amante, E. R. (2009). Chemical, sensorial and rheological properties of a new organic rice bran beverage. Rice Science, 16(3), 226234. doi:10.1016/S1672-6308(08)60083-9

Fardet, A. (2010). New hypotheses for the healthprotective mechanisms of whole-grain cereals: what is beyond fibre? Nutrition Research Reviews, 23(1), 65-134. doi:10 . 1017/S0954422410000041

FDA. U.S. Food and Drug Administration. (2003). Summary of qualified health claims subject to enforcement discretion: nuts and heart disease. Retrieved from http: / / www. fda.gov / Food / IngredientsPackagingLabeling / LabelingNutrition/ucm072926.htm

Gillingham, L. G., Harris-Janz, S., \& Jones, P. J. H. (2011). Dietary monounsaturated fatty acids are protective against metabolic syndrome and cardiovascular disease risk factors. Lipids, 46(3), 209-228. doi:10 . 1007/s11745-010-3524-y 
Nut and cereal vegetable milks $\mid 119$

Gokavi, S., Zhang, L., Huang, M.-K., Zhao, X., \& Guo, M. (2005). Oat-based symbiotic beverage fermented by lactobacillus plantarum, lactobacillus paracasei ssp. casei, and lactobacillus acidophilus. Journal of Food Science, 70(4), M216-M223. doi:10. 1111/j.1365-2621.2005.tb07191.x

Granato, D., Branco, G. F., Nazzaro, F., Cruz, A. G., \& Faria, J. A. (2010). Functional foods and nondairy probiotic food development: trends, concepts, and products. Comprehensive Reviews in Food Science and Food Safety, 9(3), 292-302. doi:10 . 1111/j.1541-4337.2010.00110.x

Gupta, S., Cox, S., \& Abu-Ghannam, N. (2010). Process optimization for the development of a functional beverage based on lactic acid fermentation of oats. Biochemical Engineering Journal, 52(2-3), 199-204. doi:10.1016/j.bej.2010.08.008

Hegde, P., Rajasekaran, N., \& Chandra, T. (2005). Effects of the antioxidant properties of millet species on oxidative stress and glycemic status in alloxan-induced rats. Nutrition Research, 25(12), 11091120. doi:10.1016/j.nutres.2005.09.020

Helland, M., Wicklund, T., \& Narvhus, J. (2004). Growth and metabolism of selected strains of probiotic bacteria, in maize porridge with added malted barley. International Journal of Food Microbiology, $91(3)$, 305313. doi:10.1016/j.ijfoodmicro.2003.07.007

Hollis, J. \& Mattes, R. (2007). Effect of chronic consumption of almonds on body weight in healthy humans. British Journal of Nutrition, 98(3), 651-656. doi:10.1017/ S007114507734608

Iacono, G., Lospalluti, M., Licastro, G., \& Scalici, C. (2008). A new formula based on almond milk for management of cow milk intolerance and food allergies. Digestive and Liver Disease, 40(10), A118. Retrieved from http://www.dldjournalonline. com / article / S1590 - 8658(08 ) 00571 - 9 / fulltext

Jing, P. \& Hu, X. (2012). Nutraceutical properties and health benefits of oats. In Cereals and pulses (pp. 21-36). Wiley-Blackwell. doi:10.1002/9781118229415.ch3
Jones, J. L., Fernandez, M. L., McIntosh, M. S., Najm, W., Calle, M. C., Kalynych, C., ... Lerman, R. H. (2011). A mediterraneanstyle low-glycemic-load diet improves variables of metabolic syndrome in women, and addition of a phytochemical-rich medical food enhances benefits on lipoprotein metabolism. Journal of Clinical Lipidology, 5(3), 188-196. doi:10.1016/j.jacl.2011.03. 002

Kaur, K. D., Jha, A., Sabikhi, L., \& Singh, A. (2011). Significance of coarse cereals in health and nutrition: a review. Journal of Food Science and Technology, 1-13.

Kaur, S. \& Das, M. (2011). Functional foods: an overview. Food Science and Biotechnology, 20(4), 861-875. doi:10.1007/s10068-011$0121-7$

Kelly, J. H., Jr. \& Sabate, J. (2006). Nuts and coronary heart disease: an epidemiological perspective. British Journal of $\mathrm{Nu}$ trition, 96 (1, 2), S61-S67. doi:10.1017/ BJN20061865

Kemppainen, T., Heikkinen, M., Ristikankare, M., Kosma, V.-M., \& Julkunen, R. (2009). Effect of unkilned and large amounts of oats on nutritional state of celiac patients in remission. e-SPEN, the European e-Journal of Clinical Nutrition and Metabolism, 4(1), e30-e34.

Koksal, A., Artik, N., Simsek, A., \& Gunes, N. (2006). Nutrient composition of hazelnut (corylus avellana 1.) varieties cultivated in turkey. Food Chemistry, 99(3), 509-515. doi:10.1016/j.foodchem.2005.08.013

Larsson, S., Giovannucci, E., Bergkvist, L., \& Wolk, A. (2005). Whole grain consumption and risk of colorectal cancer: a population-based cohort of 60000 women. British Journal of Cancer, 92(9), 18031807. doi:10.1038/sj.bjc.6602543

Léder, I. (2004). Sorghum and millets. Cultivated Plants, Primarily as Food Sources. Retrieved from http://www.eolss.net

Li, T. Y., Brennan, A. M., Wedick, N. M., Mantzoros, C., Rifai, N., \& Hu, F. B. (2009). Regular consumption of nuts is associated with a lower risk of cardiovascular disease in women with type 2 diabetes. The Journal of nutrition, 139(7), 1333-1338. 
Liu, R. H. (2012). Health benefits of phytochemicals in whole foods. Nutritional Health: Strategies for Disease Prevention, 293-310.

Luengo, M. (2009). La almendra y otros frutos secos: castaña, pistacho, piñon, nuez. Buenos Aires: Oceano-Ambar.

Mandalari, G., Nueno-Palop, C., Bisignano, G., Wickham, M. S. J., \& Narbad, A. (2008). Potential prebiotic properties of almond (amygdalus communis 1.) seeds. Applied and Environmental Microbiology, 74(14), 4264-4270. doi:10.1128/AEM.00739-08

Marcone, M. F., Kakuda, Y., \& Yada, R. Y. (2003). Amaranth as a rich dietary source of $\beta$-sitosterol and other phytosterols. Plant Foods for Human Nutrition, 58(3), 207-211.

Marotti, I., Bregola, V., Aloisio, I., Di Gioia, D., Bosi, S., Di Silvestro, R., ... Dinelli, G. (2012). Prebiotic effect of soluble fibres from modern and old durum-type wheat varieties on lactobacillus and bifidobacterium strains. Journal of the Science of Food and Agriculture, 92(10), 2133-2140. doi:10.1002/jsfa.5597

Marques, C., D'auria, L., Cani, P. D., Baccelli, C., Rozenberg, R., Ruibal-Mendieta, N. L., .. Delzenne, N. M. (2007). Comparison of glycemic index of spelt and wheat bread in human volunteers. Food Chemistry, 100(3), 1265-1271. doi:10.1016/j. foodchem.2005. 10.003

Martensson, O., Oste, B., \& Holst, O. (2002). The effect of yoghurt culture on the survival of probiotic bacteria in oat-based, non-dairy products. Food Research International, 35(8), 775-784. doi:10 . 1016/ S0963-9969(02)00074-1

Martensson, O., Oste, R., \& Holst, O. (2000). Lactic acid bacteria in an oat-based non-dairy milk substitute: fermentation characteristics and exopolysaccharide formation. Lebensmittel-Wissenschaft UndTechnologie-Food Science and Technology, 33(8), 525-530. doi:10.1006/fstl.2000.0718

Marti, V., Martinez, O., Miralles, A., \& Perez, M. (2005). Product which is fermented without lactose from a shake comprising non-vegetable dried fruits and/or orgeat. WO Patent App. PCT/ES2005/070,053.
Google Patents. Retrieved from https : / / www . google . com / patents / WO2005104862A1?cl=en

Marti, V., Martinez, O., Miralles, A., \& Perez, M. (2010). Producto fermentado sin lactosa a partir de batido de frutos secos sin legumbres y/o horchata. WO 2005/104862.

Mattes, R. D., Kris-Etherton, P. M., \& Foster, G. D. (2008). Impact of peanuts and tree nuts on body weight and healthy weight loss in adults. The Journal of nutrition, 138(9), 1741S-1745S. Retrieved from http: //jn.nutrition.org/

McKevith, B. (2004). Nutritional aspects of cereals. Nutrition Bulletin, 29(2), 111-142. doi:10.1111/j.1467-3010.2004.00418.x

McMaster, L., Kokott, S., Reid, S., \& Abratt, V. (2005). Use of traditional african fermented beverages as delivery vehicles for bifidobacterium lactis dsm 10140. International Journal of Food Microbiology, 102(2), 231237. doi:10.1016/j.foodmicro.2004.12.013

Mellen, P. B., Walsh, T. F., \& Herrington, D. M. (2008). Whole grain intake and cardiovascular disease: a meta-analysis. Nutrition Metabolism and Cardiovascular Diseases, 18(4), 283-290. doi:10.1016/j . numecd . 2006.12 .008

Mepba, H. D., Achinewhul, S. C., \& Pillay, M. (2009). Stabilised cocosoy beverage: physicochemical and sensory properties. Journal of the Science of Food and Agriculture, 86(12), 1839-1846. doi:10.1002/jsfa. 2506

Mercanligil, S. M., Arslan, P., Alasalvar, C., Okut, E., Akgul, E., Pinar, A., ... Shahidi, F. (2007). Effects of hazelnut-enriched diet on plasma cholesterol and lipoprotein profiles in hypercholesterolemic adult men. European Journal of Clinical Nutrition, 61(2), 212-220. doi:10 . 1038/ sj . ejcn . 1602518

Murtaugh, M., Jacobs, D., Jacob, B., Steffen, L., \& Marquart, L. (2003). Epidemiological support for the protection of whole grains against diabetes. Proceedings of the Nutrition Society, 62(1), 143149. 7th International Vahouny Fibre Symposium, ROYAL COLL PHYS, EDIN- 
Nut and cereal vegetable milks $\mid 121$

BURGH, SCOTLAND, MAY 27-30, 2002. doi:10.1079/PNS2002223

Myers, J. L. \& Allen, J. C. (2012). Nutrition and inflammation insights on dietary pattern, obesity, and asthma. American Journal of Lifestyle Medicine, 6(1), 14-17.

Navarro-Muñoz. (1996). El almendro: variedades y técnicas de cultivo. Andalucia: Consejeria de Agricultura y Pesca.

Nyanzi, R., Jooste, P. J., Abu, J. O., \& Beukes, E. M. (2010). Consumer acceptability of a synbiotic version of the maize beverage mageu. Development Southern Africa, 27(3), 447-463. doi:10 . 1080 / 0376835X . 2010.498955

Okarter, N. \& Liu, R. H. (2010). Health benefits of whole grain phytochemicals. Critical Reviews in Food Science and Nutrition, 50(3), 193-208. doi:10.1080/10408390802248734

Organic Monitor. (2006). The european market for soya milk \& non-dairy drinks. Dublin: Research \& Markets.

Osca, J. (2007). Cultivos herbáceos extensivos: cereales. Valencia: Editorial UPV.

Ozdemir, M., Ackurt, F., Kaplan, M., Yildiz, M., Loker, M., Gurcan, T., ... Seyhan, F. (2001). Evaluation of new turkish hybrid hazelnut (corylus avellana 1.) varieties: fatty acid composition, alpha-tocopherol content, mineral composition and stability. Food Chemistry, 73(4), 411-415. doi:10 . 1016/S0308-8146(00)00315-0

Ozen, A. E., Pons, A., \& Tur, J. A. (2012). Worldwide consumption of functional foods: a systematic review. Nutrition Reviews, 70(8), 472-481. doi:10.1111/j . 1753-4887.2012.00492.x

Ozer, D., Akin, S., \& Ozer, B. (2005). Effect of inulin and lactulose on survival of lactobacillus acidophilus la-5 and bifidobacterium bifidum bb-02 in acidophilus-bifidus yoghurt. Food Science and Technology International, 11(1), 19-24. doi:10.1177/ 1082013205051275

Packaged Facts. (2012). Dairy alternative beverages in the u.s.: soy milk, almond milk, rice milks and other dairy milk alternatives. Retrieved from https://www. packagedfacts. com/Soy-Milk-Dairy-6504961/
Patel, H., Pandiella, S., Wang, R., \& Webb, C. (2004). Influence of malt, wheat, and barley extracts on the bile tolerance of selected strains of lactobacilli. Food microbiology, $21(1), 83-89$.

Pereda, J., Ferragut, V., Quevedo, J., Guamis, B., \& Trujillo, A. (2007). Effects of ultrahigh pressure homogenization on microbial and physicochemical shelf life of milk. Journal of Dairy Science, 90(3), 1081-1093. doi:http://dx.doi.org/10.3168/jds.S00220302(07)71595-3

Pereyra, R. \& Mutilangi, W. (2012). Method for preparing high acid rtd whole grain beverages. US Patent App. 13/414,184. Google Patents. Retrieved from http : / / www . google.com/patents/US20120244249

Perrin, S., Grill, J., \& Schneider, F. (2000). Effects of fructooligosaccharides and their monomeric components on bile salt resistance in three species of bifidobacteria. Journal of Applied Microbiology, 88(6), 968-974. doi:10.1046/j.1365-2672.2000. 01070.x

Phillips, K., Ruggio, D., \& Ashraf-Khorassani, M. (2005). Phytosterol composition of nuts and seeds commonly consumed in the united states. Journal of Agricultural and Food Chemistry, 53(24), 9436-9445. doi:10. 1021/jf051505h

Piergiovanni, A. R., Simeone, R., \& Pasqualone, A. (2009). Composition of whole and refined meals of kamut under southern italian conditions. In S. Pierucci (Ed.), Icheap9: 9th international conference on chemical and process engineering, pts 1-3 (Vol. 17, pp. 891-896). Chemical Engineering Transactions. 9th International Conference on Chemical and Process Engineering, Rome, ITALY, MAY 10-13, 2009. doi:10.3303/ CET0917149

Prior, R. \& Gu, L. (2005). Occurrence and biological significance of proanthocyanidins in the american diet. Phytochemistry, 66 (18), 2264-2280. 4th Tannin Conference held at the Fall Meeting of the AmericanChemical-Society, Cellulose \& Renewable Mat Div, Phildelphia, PA, 2004. doi:10 . 1016/j.phytochem.2005.03.025 
Raghavendra, S. N. \& Raghavarao, K. S. M. S. (2010). Effect of different treatments for the destabilization of coconut milk emulsion. Journal of Food Engineering, 97(3), 341-347. doi:10.1016/j.jfoodeng.2009.10. 027

Rajaram, S., Connell, K. M., \& Sabate, J. (2010). Effect of almond-enriched highmonounsaturated fat diet on selected markers of inflammation: a randomised, controlled, crossover study. British Journal of Nutrition, 103(6), 907-912. doi:10.1017/ S0007114509992480

Ranhotra, G., Gelroth, J., Glaser, B., \& Lorenz, K. (1996). Nutrient composition of spelt wheat. Journal of Food Composition and Analysis, 9(1), 81-84. doi:http://dx.doi. org/10.1006/jfca.1996.0009

Rosburg, V., Boylston, T., \& White, P. (2010). Viability of bifidobacteria strains in yogurt with added oat beta-glucan and corn starch during cold storage. Journal of Food Science, 75(5), C439-C444. doi:10.1111/j . 1750-3841.2010.01620.x

Ruibal-Mendieta, N., Delacroix, D., Mignolet, E., Pycke, J., Marques, C., Rozenberg, R., ... Larondelle, Y. (2005). Spelt (triticum aestivum ssp spelta) as a source of breadmaking flours and bran naturally enriched in oleic acid and minerals but not phytic acid. Journal of Agricultural and Food Chemistry, 53(7), 2751-2759. doi:10.1021/ jf048506e

Salas-Salvado, J., Casas-Agustench, P., Murphy, M. M., Lopez-Uriarte, P., \& Bullo, M. (2008). The effect of nuts on inflammation. Asia Pacific Journal of Clinical Nutrition, 17(1), 333-336. $10^{t} h$ Asian Congress of Nutrition, Taipei, TAIWAN, SEP, 2007. Retrieved from http://apjcn.nhri.org.tw/

Salmeron, I., Fucinos, P., Charalampopoulos, D., \& Pandiella, S. S. (2009). Volatile compounds produced by the probiotic strain lactobacillus plantarum ncimb 8826 in cereal-based substrates. Food Chemistry, 117(2), 265-271. doi:10.1016/j.foodchem. 2009.03.112

Sanchez-Zapata, E., Fernandez-Lopez, J., \& Angel Perez-Alvarez, J. (2012). Tiger nut (cyperus esculentus) commercializa- tion: health aspects, composition, properties, and food applications. Comprehensive Reviews in Food Science and Food Safety, 11(4), 366-377. doi:10.1111/j.1541-4337. 2012.00190.x

Sanful, R. E. et al. (2009). Production and sensory evaluation of tigernut beverages. Pakistan Journal of Nutrition, 8(5), 688-690.

Sanz-Penella, J. M., Wronkowska, M., SoralSmietana, M., \& Haros, M. (2013). Effect of whole amaranth flour on bread properties and nutritive value. LWT-food Science And Technology, 50(2), 679-685. doi:10.1016/j. lwt.2012.07.031

Saura, F., Cañellas, J., \& Soler, L. (1988). La almendra: composición, variedades, desarrollo y maduración. Madrid: Instituto Nacional de Investigaciones Agrarias.

Scalbert, A. \& Williamson, G. (2000). Dietary intake and bioavailability of polyphenols. Retrieved from http://jn.nutrition.org/

Schatzkin, A., Park, Y., Leitzmann, M. F., Hollenbeck, A. R., \& Cross, A. J. (2008). Prospective study of dietary fiber, whole grain foods, and small intestinal cancer. Gastroenterology, 135(4), 1163-1167. doi:10.1053/j.gastro.2008.07.015

Segura, R., Javierre, C., Lizarraga, M. A., \& Ros, E. (2006). Other relevant components of nuts: phytosterols, folate and minerals. British Journal of Nutrition, 96 (1, 2), S36S44. doi:10.1017/BJN20061862

Sendra, E., Fayos, P., Lario, Y., FernandezLopez, J., Sayas-Barbera, E., \& PerezAlvarez, J. A. (2008). Incorporation of citrus fibers in fermented milk containing probiotic bacteria. Food Microbiology, 25(1), 13-21. doi:10.1016/j.fm.2007.09.003

Severson, D. (1998). Lactic acid fermentations (E. A. Milwaukee, Ed.). Reed TWNaG (ed). Nutritional requirements of commercially important microorganisms.

Sharma, A. \& Kapoor, A. C. (1996). Levels of antinutritional factors in pearl millet as affected by processing treatments and various types of fermentation. Plant Food Hum Nutr, 49(3), 241-252. doi:10.1007/ bf01093221

Sierra, S., Lara-Villoslada, F., Olivares, M., Jimenez, J., Boza, J., \& Xaus, J. (2005). 
Nut and cereal vegetable milks $\mid 123$

Increased immune response in mice consuming rice bran oil. European Journal of Clinical Nutrition, 44(8), 509-516. doi:10. 1007/s00394-005-0554-y

Sirato-Yasumoto, S., Katsuta, M., Okuyama, Y., Takahashi, Y., \& Ide, T. (2001). Effect of sesame seeds rich in sesamin and sesamolin on fatty acid oxidation in rat liver. Journal of Agricultural and Food Chemistry, 49(5), 2647-2651. doi:10.1021/jf001362t

Soccol, C. R., Vandenberghe, L. P. d. S., Spier, M. R., Medeiros, A. B. P., Yamaguishi, C. T., Lindner, J. D. D., ... ThomazSoccol, V. (2010). The potential of probiotics: a review. Food Technology and Biotechnology, 48(4), 413-434. Retrieved from http://hrcak.srce.hr/file/92463

Sri Lanka Medical Association. (2006). Coconuts fats. the ceylon medical journal. Retrieved from http / / www . sljol. info / index . php / CMJ/article/.../1200

Stone, D. (2011). Emerging trend of dairy-free almond milk. Food Magazine. Retrieved from http : / / www . foodmag . com . au / news / emerging-trend-of-dairy-free-almond-milk

Stuckler, D. \& Basu, S. (2011). Evaluating the health burden of chronic diseases. In D. Struckler and K. Siegel (Eds.) Sick societies: Responding to the global challenge of chronic disease. New York: Oxford University press.

Sze-Tao, K. \& Sathe, S. (2000). Walnuts (juglans regia 1): proximate composition, protein solubility, protein amino acid composition and protein in vitro digestibility. Journal of the Science of Food and Agriculture, 80(9), 1393-1401. doi:10.1002/1097-0010(200007) 80:9〈1393::AID-JSFA653〉3.0.CO;2-F

Tey, S. L., Brown, R. C., Chisholm, A. W., Delahunty, C. M., Gray, A. R., \& Williams, S. M. (2011). Effects of different forms of hazelnuts on blood lipids and alphatocopherol concentrations in mildly hypercholesterolemic individuals. European Journal of Clinical Nutrition, 65(1), 117124. doi:10.1038/ejcn.2010.200

Thompson, T. (2003). Oats and the gluten-free diet. Journal of the American Dietetic Association, 103(3), 376-379. doi:10.1053/ jada.2003.50044
Thondre, P. S., Ryan, L., \& Henry, C. J. K. (2011). Barley beta-glucan extracts as rich sources of polyphenols and antioxidants. Food Chemistry, 126(1), 72-77. doi:10. 1016/j.foodchem.2010.10.074

Triantafyllou, A. (2002). Non-dairy containing milk substitute products. WO Patent App. PCT/IB2002/001,759. Google Patents. Retrieved from http: / / www.google.com / patents/WO2002065855A3?cl=en

Valencia-Flores, D. C., Hernandez-Herrero, M., Guamis, B., \& Ferragut, V. (2013). Comparing the effects of ultra-high-pressure homogenization and conventional thermal treatments on the microbiological, physical, and chemical quality of almond beverages. Journal of Food Science, 78(2), E199E205. doi:10.1111/1750-3841.12029

van de Vijver, L. P. L., van den Bosch, L. M. C., van den Brandt, P. A., \& Goldbohm, R. A. (2009). Whole-grain consumption, dietary fibre intake and body mass index in the netherlands cohort study. European Journal of Clinical Nutrition, 63(1), 31-38. doi:10.1038/sj.ejcn.1602895

Vinson, J. A. \& Cai, Y. (2012). Nuts, especially walnuts, have both antioxidant quantity and efficacy and exhibit significant potential health benefits. Food \& Function, 3(2), 134-140. doi:10.1039/c2fo10152a

Wang, X., Conway, P. L., Brown, I. L., \& Evans, A. J. (1999). In vitro utilization of amylopectin and high-amylose maize (amylomaize) starch granules by human colonic bacteria. Applied and environmental microbiology, 65(11), 4848-4854. Retrieved from http://aem.asm.org/

Ward, H. A., Keogh, R., Lentjes, M., Luben, R. N., Wareham, N. J., \& Khaw, K.-T. (2012). Fibre intake in relation to serum total cholesterol levels and chd risk: a comparison of dietary assessment methods. European Journal of Clinical Nutrition, 66 (3), 296-304. doi:10.1038/ejcn.2011.184

Ward, J. L., Poutanen, K., Gebruers, K., Piironen, V., Lampi, A.-M., Nystrom, L., ... Shewry, P. R. (2008). The healthgrain cereal diversity screen: concept, results, and prospects. Journal of Agricultural and 
Food Chemistry, 56(21), 9699-9709. doi:10. 1021/jf8009574

Welch, R. \& McConnell, J. (2001). Oats. Cereals and Cereal Products - Chemistry and Technology, 367-390. Aspen Publishers Inc., Maryland.

Whent, M., Huang, H., Xie, Z., Lutterodt, H., Yu, L., Fuerst, E. P., ... Luthria, D. (2012). Phytochemical composition, antiinflammatory, and antiproliferative activity of whole wheat flour. Journal of Agricultural and Food Chemistry, 60 (9), 21292135. doi:10.1021/jf203807w

Wu, W.-H., Kang, Y.-P., Wang, N.-H., Jou, H.-J., \& Wang, T.-A. (2006). Sesame ingestion affects sex hormones, antioxidant status, and blood lipids in postmenopausal women. The Journal of nutrition, 136(5), 1270-1275. Retrieved from http://jn . nutrition.org/.

Zambón, D., Sabaté, J., Muñoz, S., Campero, B., Casals, E., Merlos, M., ... Ros, E. (2000). Substituting walnuts for monounsaturated fat improves the serum lipid profile of hypercholesterolemic men and womena randomized crossover trial. Annals of Internal Medicine, 132(7), 538-546. doi:10.7326/ 0003-4819-132-7-200004040-00005

Zhu, N., Sheng, S., Sang, S., Jhoo, J., Bai, N., Karwe, M., ... Ho, C. (2002). Triterpene saponins from debittered quinoa (chenopodium quinoa) seeds. Journal of Agricultural and Food Chemistry, 50(4), 865-867. doi:10.1021/jf0110021

Zielinski, H., Ceglinska, A., \& Michalska, A. (2008). Bioactive compounds in spelt bread. European Food Research and Technology, 226(3), 537-544. doi:10 . 1007 / s00217-007-0568-1 